\title{
THE CLINICAL AND HISTOPATHOLOGICAL STUDIES ON THE WINDOW OPERATION FOR THE CHRONIC MAXILLARY SINUSITIS \\ By
}

TAKAYASU SUZUKI, M.D.

Department of Oto-rhino-laryngology, Yokohama University, School of Medicine (Director: Prof. T. Kashizuado)

I. The author performed the window operation for the chronic maxillary sinusitis and investigated the relation between the postoperative course and the histopathological findings of the maxillary mucous membranes which were removed from the cases. Ninety-two cases of chronic maxillary sinusitis were selected for the study. For the maxillary sinusitis accompanied by the ethmoidal sinusitis and / or septal deviation, the endonasal ethmoidectomy and/or submucous resection of the septum were performed.

Part of the maxillary mucous membrane removed during the operation was stained with haematoxylin-eosin and other staining techniques. The postoperative courses of the cases were followed up for $1 /$ 2-2 years. They were classified into 4 groups in 6 months postoperatively, namely, good after effect, fair after effect, no change and worse. The results were : $48 \%, 32 \%, 16 \%$ and $4 \%$, respectively.

II. The histopathological findings were classified into four types, i.e., edematous, infiltrating, fibrous and mixed. Each type was observed as with grade of, low and high. The results were summarized as follows :

1) Whether the histopathological change of the mucous membrane was high or low, both the edematous and infiltrating types were inclined to clinical cure by the operation. Therefore, both types might indicate the window operation

2) For the fibrous type, the higher was the pathology of mucous membrane, the better the postoperative cure showed after window operation. This sug. gested that the fibrous type was also indication of the operation.

3) For the mixed type there was no significant relationship between the pathology and clinical course after operation. It was difficult to determine the indication of the maxillary window operation for this type.

III. Following the above date, the special connective tissue stainings were performed for 20 selected cases of the fibrous or mixed types of mucous membrane. The following results were obtained.

1) Elastic fibers were fourd distributed in the wall of vessels or cystically expanded glands without any mutual relation between the histopathological types and the degree of elastic fiber distribution.

2) The distribution of reticular fibers were more dense in mixed type than in fibrous type. The reticular fibers might grow to the collagen fibers.

3) In the advanced fibrous type, mature collagen fibers increased, while the capillaries decreased. This suggested that the inflammatory process was ceasing and the repairing mechanisms started to proceed. 


\title{
上顎洞開空手術に関する臨床的ならびに 病理組織学的研究
}

\author{
横浜市立大学医学部耳离咽喉科学教室（主任：柏戸貞一教授）
}

大学院学生鈴李高巷

目次

I 緒 事

II 前編 慢性上顎洞炎に対する䦎空手術に関する臨 床的研究

第 1 章 楮

第2 章 研倇対象おょび研㠾方法

第 3 章 研究成綎

第 4 章 綜插ならびに考按

第 5 笪 結 諾

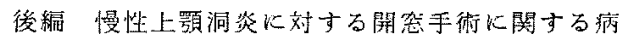
理組铰学的研昆

第 1 章 緒

第2 章 研究対㯒および研究方法

第 3 晅

第 1 節 粘膜病型, 病变度と䟧床経過との関倸

第 2 節粘膜病型, 病変度と結合組織線維との関 你

第 4 章 綜括ならびに考按

第 5 章 結 語

III 全編に対する棕括ならびに考按

N 結 語

\section{I 緒言}

一般に慢性副學腔炎の治療法は副算腔そのものの構造 並びに機能の複雑なため，かなりの多様性を示し莧物寮 法，外科療法など色々の意見がかなり錯綜している。

これに対し従来慢性上顎洞炎の外科潦法については古 くから、、わ和る Caldwell-Luc 氏法が最も普遍的且つ 根治的方法とされていた。

しかしこれに対し，以加る上影洞開空手術当近年次 第にその有用性が認められ，かなりに臨床的応用を見 るようになつてきた (Ziegelmann"), Mikulicz"), Van Alyea $^{3)}$, Sturmann-Canfield, 佐々末十). またしかしな がらこの見解に対し一部の諸家からの反論がない訳では
ない。その第一とするむのは一度病変に宿つた副臱腔粘 膜任果して再び正常の粘膜に復し得るか否かっ、したがつ てこの問題の完全な解決が行なわれなれけば，開空手術 は決定的療法となし得ないとするものである。

第二の反対は下鼻道側壁に空孔を作る時は，鼻内気流 は著明な変化を受け，この為上顎洞の正常化は益々困難 になるであるうとするものである（高橋，Cottle）. しか もこれに封する開空手術の効果については報告者により その成續はかかりの違いがある。

しかし近年炎症治療の薄物は著明に進步した（抗生

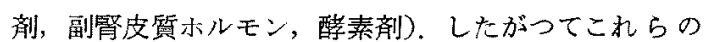
薬物進步の現況下に招いては炎症治療に単なる外科切除 のみを唯一の療法とすることが出来なくなつた。この意 味から改めてここに上顎洞開空手術につき研究を行なう

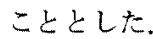

II 前編 慢性上顎洞㷋に対する開空手 術に関寸る臨床的研究

\section{第 1 章 緒言}

上頻洞に対する開空手術は 1886年 Mikulicz ${ }^{2)}$ が下塞 道より上顎洞に対孔を開けたのが始まりである。欧米で は以苯，上くこの方法が行なわれ，主上して経下奥道的 に釹子(trocar) を用いて空孔を作ることが多いよ5であ る.1921年 Barlow ${ }^{5}$ は 100 例に開空手術を行ない $47 \%$ が治程した上述べ，症状の上扎なかつたのは，充分大き な空孔を開けられなかつたたかであるとしている。

1927年 Hempstead ${ }^{63}$ は病的粘膜も機能ある組織とみな し，鼻内上り対孔をつくり，洞内忙前壁をのぞき充分観 察し，肉眼的に病的な粘膜のみ䍂除している。

1934年 Goodyear ${ }^{7)}$ は Caldwell-Luc 氏手術後におい ては，洞内は肥厚した結合組織で充たされ，相当な例に 㬟嗹や再感染をみたが，開空手術後においては，極端に 組織の肥嬮した例をみなかつたが，これは粘膜を涂離し なかつたためであるうと述べ，效果のない例や悪化した 
例は，対孔が常に具合が悪いという印象をうけたとして いる。

本邦でも既に浜地氏はこれを行なつておるが，最近佐 ヶ木゙は成人の慢性上顎洞资に対する開空手術上根治手 術後の経過を，対孔よりの肉眼的観察によつて比較し， その洞内粘膜所見上分泌物の量および性質の変遷より， 病变於高度であつても開空手術によつて正常粘膜に戻る 傾向があるとした。

な怙Van Alyea も絶望的な状態ではなく，この疾患の始まりや遷延する のは, 主として塞がれた排泄路の結果であり, その原因 は自然孔そのものの久陌ではなく，隣接器官と自然孔と の間の障害によるとしている。すなわち，急性炎症時の

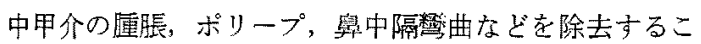
とによって，かなりの改善がみられる、これらに対する 処置をのがすと慢性上顎洞炎に移行し，この状態となる 々萁剂（抗生剂，醏素郕）の投与も効果が期待できず, 何ら加の排泄路をつくる必要にせまられる。このため開 密手術が必要となるとした。

以上の考察にしたがつて私はまず，しかる可き症例に つき下鼻道側壁上り上須洞に向い，開空手術在行ない，そ の結果如何様な成績を得るかを実際の症例につき検討す ることとした，その際第一に症例の撰定に工夫するとと もに，手術法そのものにもある程度の工夫を行なつた。 またその成績を 教室において行なわれた Caldwell-Luc 氏手術の成績とも比較した。

\section{第 2 章 研究対象および研究方法}

症例は横浜市大医学部病院, 国立相模原病院および横 洪南共済病院において1964年10月より1966年12月までの 2 年 3 カ月にわたつて自覚的にも他覚的にも慢性副鼻腔 炎上認められるものを撰んだ，その場合, 炎症々状高度 で，いわゆる根治手術を必要々すると思われるものは出 来るだけ除外した．屯た炎症が上顎洞に限局している場 合には開空手術のみを行ない，節骨洞炎を伴なつている 場合には，開空手術のほか，鼻内的節骨洞削開術を加 え, 必要に応じて奥中隔矯正術, 中, 下甲介切除を行な つた。

その結果患者総数法71人，病症例92である。性別では 男 45 人 56 症例, 女 26 人 36 症例で, 患側は右側 41 例, 左側 51例である。年令別分布は第 1 表の通りである。

手術法は一部症例については Sturmann-Canfield の鼻 内法に従つたが，大多数例は，空孔の閉鎖を防ぐため口 腔前庭の粘膜を切開し, 下與道に讋当する梨状孔縁部老

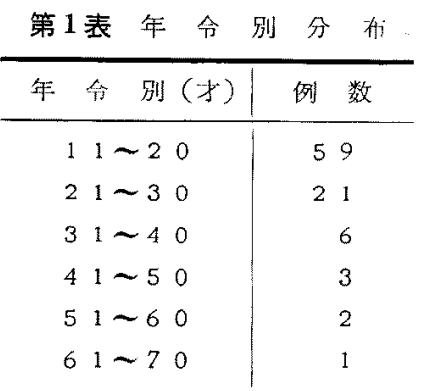

繁除し，上顎洞前内方の一部を開放しつつ下䋰道側壁骨 壁を上㖽洞粘膜上共に切除し，ついで空孔に近接した洞 底粘膜の必要部を除去して，固有舆腔の粘膜は Bcenninghaus の开として上㖽洞側に倒した。このとき不良 肉芽の增生を防ぐため，残置された洞粘膜の断端とこの 升の断端が接合するように努めたままた前庭部の粘膜の 切開部も肉芽の上顎洞内增生，進入を防くため必ず骨膜 繾合を行なつた。

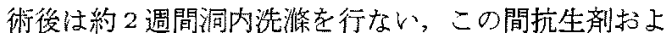
び醅妻剂を投与した（第 2 表）。

第 2 表栾物使用の状沉

\begin{tabular}{|c|c|}
\hline 薬物の種類揖よび使用期間 & $\begin{array}{c}\text { 奏例数 } \\
(\text { (例) }\end{array}$ \\
\hline 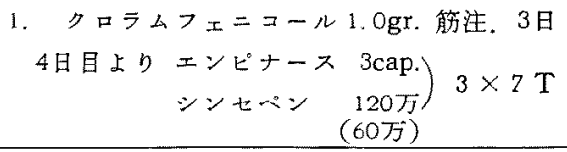 & 27 \\
\hline 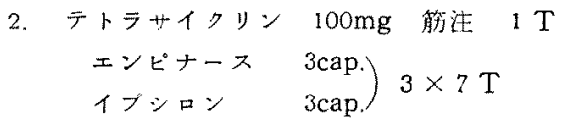 & 20 \\
\hline
\end{tabular}

3. クロラムフェニコール1, Ogr. 筋注 $2 \mathrm{~T}$ クロラムフェニコール1.0 $4 \times 5 \mathrm{~T}$

\begin{tabular}{ll|l|l}
\hline 4. テトラサイクリン & $\begin{array}{c}750 \mathrm{mg} \\
3 \times 10 \mathrm{~T}\end{array}$ & 6 \\
\hline 5. その他 & & 4 \\
\hline
\end{tabular}

ついで開空手術後 6 カ月の臨床経過をアンケートによ り調查するとともに一部症例については他覚的舅内所

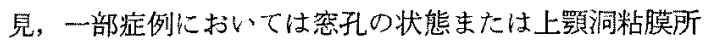
芫を antroscope をもつて観察した。

な抢この研究と比較するため教室において CaldwellLuc 氏手術をうけた症例の適当数についても同様の調查 
さ行なつた。

\section{第3章 研究成繀}

以上の方法に上つて観察した結果，自覚的扔よび他覚 的に経過良好なる群在良好群，自営症状あるい他覚的 所見の一方が上れない群を軽快群，自，他敩的に症状， 助内所見の改善を双ないもの不变群. 自, 他觉的に術 前より悪化したと思われるものを悪化群とするときは第 ろ表のような結果しなる。

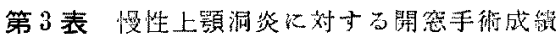

\begin{tabular}{|c|c|c|c|c|c|}
\hline 泟例数 & 良好哞 & 慗快群 & 不変群 & 悪化群 & 計 \\
\hline 奏 例 数 & 44 & 29 & 15 & 4 & 92 \\
\hline $\begin{array}{c}\text { 百分染 } \\
(\%)\end{array}$ & 48 & 32 & 16 & 4 & 100 \\
\hline
\end{tabular}

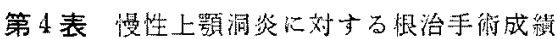

\begin{tabular}{|c|c|c|c|c|c|}
\hline 在例数 & 是好磁 & 整快票 & 不筮群 & 熹化政 & 計 \\
\hline 奏例数 & 24 & 33 & 1 & 4 & 62 \\
\hline $\begin{array}{c}\text { 百 } \\
(\%)\end{array}$ & 39 & 53 & 2 & 6 & 100 \\
\hline
\end{tabular}

ここで開空手術成績上比較するため慢性上顎洞炎に対 して教室において Caldwell-Luc 氏手術党行ない，術後 6 力月以上を経た62症例に対してアンケートを求め同様 に処理したところ第 4 表のようであつた。

次に根治手術の場合，名越 た洞内はほぼ 3ー4力月経過する上肉芽組織によつて充 たされるこしになる。この肉芽の增生の仕方は複雑で， 洞の発奇の良否, 術前の粘膜病変の性質, 体質, 栄盖な どいろいろ影響をうけ，その多彩度肉芽增生の原因が 治瘑機転に影響索与えている因子であるとしているが， この肉芽組織は術後の整腫ができない限り, 術後経過が 長くなつてむほぼ変化がない上考えられる。

一方開空手術の後では，反復する上気道の炎症などに よつて洞内に残置された粘膜は，多少の影響定受けるこ とは考えられる。一方ではかなり高度な病変であれば, 開密手術によつて下舅道に排泄路が作られてもその治㽷 への修復には時閒を要することも推測され，実際にも経 験する上ころである。
第 5 表 術後 6 力月拈よび 1 年 6 力月の嵒林経 過の推移 (33例)

1. 臨床経過に変化がみられない群

\begin{tabular}{|c|c|c|c|}
\hline 良 好 & 群 & 11 例 & \\
\hline 枎 & 铎 & 14例 & 26 洌 $(79 \%)$ \\
\hline 不 変 & 群 & 1 例 & \\
\hline
\end{tabular}

2.経渦ととあに良くなつた群

\begin{tabular}{|c|c|c|c|}
\hline 柽性群一 & $\rightarrow$ 良好群 & 2 例 & $00 \%$ \\
\hline 不供群 - & $\rightarrow$ 柽快洋 & 工例 & \\
\hline
\end{tabular}

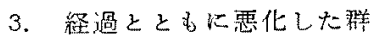

\begin{tabular}{|c|c|c|}
\hline 墪快猜 $\rightarrow$ 不变群 & 3例 & \\
\hline 良好瑟 $\rightarrow$ 埾快詳 & 1 例 & \\
\hline
\end{tabular}

第 6 表 洞内膑溜液の性状と郘佅経過との関俰 (65例)

\begin{tabular}{|c|c|c|c|c|}
\hline 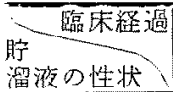 & 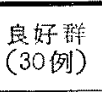 & $\begin{array}{l}\text { 整头群 } \\
\text { (17例) }\end{array}$ & $\begin{array}{l}\text { 不变群 } \\
(14 \text { 例) }\end{array}$ & 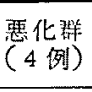 \\
\hline 存在世打 & $\begin{array}{c}11 \\
(37 \%)\end{array}$ & $(35 \%)$ & $\begin{array}{c}4 \\
(29 \%)\end{array}$ & $(25 \%)$ \\
\hline 嶈液粘液性 & $\begin{array}{c}12 \\
(40 \%)\end{array}$ & $(24 \%)$ & $(14 \%)$ & $\begin{array}{r}2 \\
(50 \%)\end{array}$ \\
\hline 膆 & $\begin{array}{c}7 \\
(23 \%)\end{array}$ & $(41 \%)$ & $\begin{array}{c}8 \\
(57 \%)\end{array}$ & $(25 \%)$ \\
\hline 計 $(\%)$ & 100 & 100 & 100 & 100 \\
\hline
\end{tabular}

第 7 表 洞站膜肥厚度々臨床経過々の関俰（65例）

\begin{tabular}{|c|c|c|c|c|}
\hline 粘膜肥厚度 & $\begin{array}{l}\text { 良好群 } \\
(30 \text { 例 })\end{array}$ & $\begin{array}{l}\text { 軽快群 } \\
\text { (17例) }\end{array}$ & $\begin{array}{l}\text { 不変群 } \\
(14 \text { 例) }\end{array}$ & $\begin{array}{l}\text { 恶化群 } \\
(4 \text { 例) }\end{array}$ \\
\hline 軗 & $(17 \%$ & $\begin{array}{c}4 \\
(23 \%)\end{array}$ & 0 & 0 \\
\hline 中 等 & $\begin{array}{c}18 \\
(60 \%)\end{array}$ & $\begin{array}{c}10 \\
(59 \%)\end{array}$ & $\left(\begin{array}{c}10 \\
(71 \%)\end{array}\right.$ & $(50 \%)$ \\
\hline 高 & $\begin{array}{c}7 \\
(23 \%)\end{array}$ & $\begin{array}{c}3 \\
(18 \%)\end{array}$ & $(29 \%)$ & $(50 \%)$ \\
\hline 棓 $(\%)$ & 100 & 100 & 100 & 100 \\
\hline
\end{tabular}

そこで開空手術後 6 力月および 1 年 6 力月を経た際の 臨床経過をアンケートによつて調べた結果は第 5 表に示 す如くである。

次に開空手術92症例のうち術後6力月以上を経て充分 経過観察のできた47人65例（良好群30例，軽快群17例， 
不変群 14 例, 悪化群 4 例) について, 手術時洞内の肉眼 的所見, 開空手術以外の外科的治潦および術後経過上空 孔の開存状態について調べた。

まず洞内眝溜液の性状と臨床経過との関係的 6 表に 示す如くである。

また洞内肉眼的所見のうち粘膜肥厚度と臨床経過との 関係は第 7 表に示す如くである。

次に開空手術を行な5場合上頡洞炎以外の疾患，すな

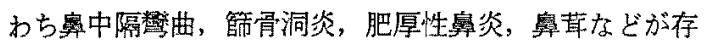
在するときこれら文取除いてすかかないと, 術後6力月を 経た俊，それらによる症状との鑑别が難しくなる、上靧 洞開空手術の臨床経過をより正しく評洒するため上記疾

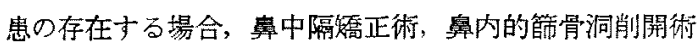
㛎よび中，下甲介切除術索行なつた。これら開空手術以 外の且内形成術上臨床経過との関係は第 8 表に示す如く である。

第 8 表上顎洞開空手術十舅内形成術之監休経 過上の閶保

\begin{tabular}{|c|c|c|c|c|}
\hline 宜内形成衔 & $\begin{array}{l}\text { 良好群 } \\
\left(\begin{array}{l}23 \text { 人 } \\
30 \text { 例 }\end{array}\right)\end{array}$ & $\left(\begin{array}{l}14 \text { 人 } \\
17 \text { 例 }\end{array}\right)$ & $\begin{array}{l}\text { 不変群 } \\
\left(\begin{array}{l}10 人 \\
14 \text { 例 }\end{array}\right)\end{array}$ & $\left(\begin{array}{ll}2 & \text { 人 } \\
4 & \text { 例 }\end{array}\right)$ \\
\hline 嶴中隔矯正術 & $\begin{array}{l}6 / 23 \\
(26 \%)\end{array}$ & $\begin{array}{l}5 / 14 \\
(36 \%)\end{array}$ & $\begin{array}{l}2 / 10 \\
(20 \%)\end{array}$ & $\left(\begin{array}{c}2 / 2 \\
(100 \%)\end{array}\right.$ \\
\hline $\begin{array}{l}\text { 経宜的䈵骨洞削 } \\
\text { 開街 }\end{array}$ & $\begin{array}{l}19 / 30 \\
(63 \%)\end{array}$ & $\begin{array}{l}10 / 17 \\
(59 \%)\end{array}$ & $\begin{array}{l}12 / 14 \\
(86 \%)\end{array}$ & $(50 \%)$ \\
\hline $\begin{array}{l}\text { 中, 下甲介切除 } \\
\text { 術 }\end{array}$ & $\begin{array}{l}12 / 30 \\
(40 \%)\end{array}$ & $\begin{array}{l}10 / 17 \\
(59 \%)\end{array}$ & $\begin{array}{l}3 / 14 \\
(21 \%)\end{array}$ & $(100 \%)$ \\
\hline 罳茸切除術 & $\begin{array}{l}3 / 30 \\
(10 \%)\end{array}$ & $\left.{ }^{0} / 0\right)^{17}$ & $\begin{array}{l}5 / 14 \\
(36 \%)\end{array}$ & $1 / 4$ \\
\hline
\end{tabular}

第9表 空孔の開存状態乙臨床経過との関俰

\begin{tabular}{|c|c|c|c|c|}
\hline 開存状態儖経過 & $\begin{array}{l}\text { 良好群 } \\
(30 \text { 则 })\end{array}$ & $\begin{array}{l}\text { 俥圣快群 } \\
\text { (12 例) }\end{array}$ & $\begin{array}{l}\text { 不変群 } \\
(14 \text { 例) }\end{array}$ & $\begin{array}{l}\text { 惡化群 } \\
(4 \text { 例 })\end{array}$ \\
\hline 開 & $\begin{array}{c}24 \\
(80 \%)\end{array}$ & $(41 \%)$ & $(29 \%)$ & $(50 \%)$ \\
\hline 狭 & $(17 \%)$ & $(35 \%)$ & $(14 \%)$ & $(25 \%)$ \\
\hline 閉 & $(3 \%)$ & $(24 \%)$ & $\begin{array}{c}8 \\
(57 \%)\end{array}$ & $(25 \%)$ \\
\hline
\end{tabular}

つぎに術後 7 力月における空孔の開存状態と臨床経過 との関倸泣第9表に示寸如くである。下鼻道より endoscope にて空孔の状態を観察するに, 開存している例は
辺緑に肉芶は少しも㒻られず，瘢痕性にほぼ円形に開い ていることが多い（写真 1)，狭空あるいは開塞してい る空孔の辺緑は肉芽様で表面に凹凸がみられ，かなりの 量の粘液性膿性の分泌液がみられるのが通例である（写 賣 2 ).

endoscope による洞内の粘膜所見では経過良好例では 肥厚の程度が弱くなつたと思われる場合には表面は平滑 で光沢があり，毛細血管の走行もわずかに琶められる。 また瘢瘨性に治㷥したと思われる場合には血管の分柯は 少なかつた。術後 6 力月を程て未だ分泌液の多い粘膜で は表面に凹』がみられ肉芽様を呈し，分必物により光を 反射している像を示し血管が充血しているように見えた (写真 3 ).

\section{第 4 章 綜括並びに考按}

以上私は自家の症例対象として独自の上顎洞開空裳 行なつた症例の，臨床䅅過並びにこ机と対称し得る Caldwell-Luc 氏手術症例，開空手術例の手術時洞内所 見, 開空手術以外に行なつた各種手術, 術後経過と空孔 開存の有無との関係, 洞内粘膜の所見などを記㦲した が，これらの成績を基礎しして開空手術の臨床的意義を 考按すると次のようである。

まず臨床例につき開空手術後及び Caldwell-Luc 氏手: 術後夫々 6 力月経過の状況を第 $3 ， 4$ 表につき比較する, 上，開密手猁に上る良好群が48\%を示し，根治手術によ つては39\%にすぎないことを知る。このことは手術適応 決定に当り開空手術の場合は重症例を避けたといらこと も関倸すると思加れる゙，これまでの根治手術が慢性上

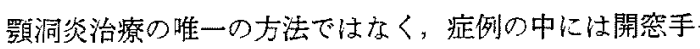
街のみによつても充分な成績加得られる例が含まれてい ることを示している，また根治手術によつて，軽快群が 53\%を示したことおよび開空手術例に不変群が16\%存在 寸ることは確かに根治手術によらなれけば臨床的治紊が 得られない症例があるということを示していると云かな れけばならない。

これに対し第 5 表の成績は開空手術後 6 力月老経た症 例ではその臨床経過注ほぼ定し，全体の78\%は術後6 カ月で臨床成績を判定できることを示している。

次に第6表の成績をみると，手術時の洞内に膿性分议 液妾含む症例が良好，轻快，不变群において殆んど同数 例を示しているのに対し，繁液，粘液性分汹液它含む割 合は，分必液の存在しない場合と同様に症例数が次第に 減つている。このことは譙液粘液性炎症の方方膿性炎症 よりも開窓手術にはより適応が大きいことを示してい 
3.

また第 7 表上り注，全体に粘膜は中等度肥厚例が最も 多く, 高度にポリープ様腫脹がみられる例は65例中16例 （25\%）であつたが，軽度例は全例良好な成績を示し， この表よりは開空手術例について，粘膜肥厚度は少ない 程, 踟床経過悢良好の上うに思われた。

次に第 8 表より，慢性上䫑洞炎がある場合50〜86\%に 箳骨洞炎を伴ない，わずかに不変群に鼻内的節骨洞削開 術を必要とする症例が多かつたことがうかがわれる。 た不変群に属する $36 \%$ に奥革切除術を行なつているが, 術後6力月経つてみると再びポリープの発生（実際には もつと早く発生しているが）をみるもの, 中舆甲介がポ リープ様に尰脹するものが多く, 反復的にポリープの発 生するような慢性上䫑洞炎は開空手術の適応ではないか の感を与える。

な㧍これら外科的療法を行度つた症例も，全体的には 経過良好群症例が多い点より，そのことによる症状の軽 快も考えられるが，開空手術が粘膜自体の修復能力に依 存するところが大きい以上，上頡洞周囲の環境をよくす ることが必要であると同時に術後成續をよくしていると 考えられる。

な打開密手術後における密孔の開存扝よび閉塞上臨床

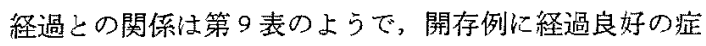
例多く，閉塞例㮸逆に症状不変の例が多くなり, 狭窄群 はその中間的㑯向を示している点はVan Alyea ${ }^{3)}$, Hempstead $^{6>}$ らの指摘する如く臨床経過に対し空孔の開閉 が大きく影響することを示していると考えられる。

以上私の臨床成績についての考察を更に各方面の諸家 の意見から検討するに，既にZuckerkandle 顎洞炎に関儿節骨漏斗上上顎洞自然排泄孔の先天的狭窄 に注目し，自然孔が最む高い部位にあるこ上はすでに不 都合なことであるとしている。ささらに蜱中隔警曲の際 の，中率甲介の側方への圧迫，節骨胞の異常形成などは すで慢性上顎洞炎発生の解剖学的な素因となりらると 述べている。

この点上り，一且慢性化し自然孔の閉塞した上顎洞炎 の治療という点から考えると, 開空手術を行ならことは 局所的要因をとり除く意味で重要であると考光られ。こ の意味において従来のいわゆる根治手術は広神 ${ }^{109}$ の指摘 する如く, 病的粘膜を切除すれば治るということ注何ら 科学的な根拠はなく，もしも排泄路がつき病变の強い部 分は去り, 抗生郕, 䣼素戍の使用によつて組織の再生が おこりうるならば，開窓手術も一つの好ましい療法では
ないかと考えられる。

後藤(敏) ${ }^{11}$ は副察膑炎手術では固有鼻腔に対孔を確保 することが手術の，治癒一の第一義的条件であることは 根治手術, 保存手術論者も一致していることからみて も，粘膜の残置は治㽷のために第二義的なものであると したが，高橋(良) $)^{122}$ は洞粘膜病変が強いと上皮機能は終 局的には元に戻りうるが，固有層病変は容易に元に杘ら ない，従つて上皮機能が回復し，固有層もこれにつれて 落付ける様な例が保存手術の対照となるとしている。 た上頻洞では下案道側壁からの antrostomy だけの場合 乙節骨洞も開放して上頻洞口を拡大開孔する場合とに大 別していると述べている.

な扔開空の手術法については第 2 章に述べたよらに特 別の工夫㠜らしているが，その事の効果怯第 9 表の成 績よりむ肯定されたが，更に開空手術の術後成績で悪化 群に属する症例に対して Caldwell-Luc 氏手術を追加し た際の，上顎洞内の状態に過剩肉芽と隔壁の形成がみら れなかつたことよりもそのことが認められた。

また開空手術後 6 力月の臨床経過と手術時にみられた 洞内賍溜液との関係については, 高須賀 ${ }^{133}$ は開空手術後 1 年半より15年交での11例に根治手術を行ない，対孔の 閉鎖群では上顎洞に粘液または膿汁の貯溜を認め，粘膜 は強く凮脹していたが，対孔の開存している群では空虚 であつたとしている.

次に慢性上顠洞次とともに鼻茸の存在する例に対し開 害手術と同時に章荤切除術を行なつた成績を考えるに， ポリープが反復する例では根治手術の方が，上り適応で あるうとしたが，このことについては Zuckerkandle ${ }^{14)}$ はポリープは常に舆漏の刺戙の加わつている領城から発 生するとした。しかし Stevenson ${ }^{15)}$ は開窟手術を行なら ことによつてボリープが消失する速さに警ろかされると している。

また传ヶ木゙) は片側開空手術，他側根本手術を行ない その臨床钼察で浮冨苗性高度肥厚群では，開空手術側で 洞の排泄通気がつくと洞粘膜は1カ月で $40 \%$ が正常に戻 り，6力月で全例 ( 5 例) が正常状態に戻り，根本手術

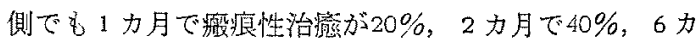
月で全例治瘾したとしている。

結局全体的には粘膜の柽度病変はもちろん高度の肥厚 があつても開空手術で良好な経過をとる症例任92例中 44 例 $(48 \%)$ に達し，その良好群に括いて密孔開存例が全 体の80\%に達し，不変群に括いて閉塞例方60\%近くある ことは, Van Alyea ${ }^{3)}$ Hempstead ${ }^{(3)}$ 後藤 $\left(\right.$ 敏 $^{11)}$ らの主 
張するよらに空孔が充分大きく開けられて排泄をつけ， それが開存しているといらことは慢性上㖽洞炎の経過に 良好な影響を与えていると考えられる。しかし更に考虑 すべきはこの間全身的又は局部的に抗生剂又は酵素剂 などの充分な治療を行なつたことであつて、これがよい 成績を収めるに可なり效があつたことと考えら机る。

\section{第 5 章 結語}

慢性上顎洞炎患者 71 人92例に対し開空手術远行ない， 術後の蹦木経過を自覚症状, 他覚的所見により良好群, 怪快群，不变群および悪化群の 4 群に分けた。その術後 6 力月目の成績は良好群 92 例中 44 例 $(48 \%)$, 㣫快群 29 例 $(32 \%)$, 不変群 15 例 $(16 \%)$, 悪化群 4 例 $(4 \%)$ て あつて，開空手術も慢性上頡洞炎治潆に执いて充分考虑 の価值があると考えられる。

なおその手術に当つては洞内の肉腿的所見において澧

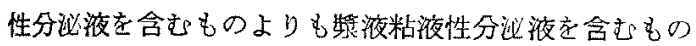
の方が臨林効果は良好であるが，空孔の開存が永く続く 症例の方がこれが閉塞する症例よりも臨床経過柱良好 であつて，この点については手術実施に当り格段の工夫 を必要とする，但し以上の良好な成績には萁物の進歩も 相当に有効に働いていると考えられる。

後編 慢性上颚洞炎に対与る開空手術に 関する病理組織学的研究

\section{第 1 章 緒 言}

慢性副鼻膑炎の 病理組織学的研究㳉 Zuckerkandle:67 (1893), Hajek ${ }^{177}$ (1910), Uffenorde ${ }^{18)}$ (1920), Schumacher ${ }^{19)}$, Eggston-Wolff ${ }^{20)}$ らにより詳紏に報告され，

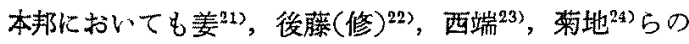
研究がある。他方 Altschuler \& Angevine ${ }^{25)}$, 估藤 ${ }^{26)}$ らの副鼻腔粘膜の組織化学的研究や，さらに近年は電子 顕微镜に上る観察も行なわれるようになつている。

しかしながら各研究とも粘膜の詳細な検索ではあるが 挀床経過との関連についての記載は必ずしも明確ではな い点に若干の不満がある。

しかるに私は今回慢性上影洞炎に対して開空手術を行 ないその効果をかなり明瞭に追究することができた。 よ つて本編に㧍いては, その際採取した洞粘膜の病理組織 学的所見を調查し臨床経過との関保を明瞭にすることを 心脚けた。

第 2 章 研究対象および研究方法

研究対象は前編第 2 章で述べた慢性上䫇洞炎患者 71 人 92例に開空手術を行なつたときに得た上顠洞の下身道㑡
壁に対応する部分の粘膜であって，これを10\%ホルマリ ンにて固定, Hematoxylin eosin 染色を行ない, 一部標 本には Van Gieson 染色, PAS 染色を行なってその病 理組織学的検卖を行なつた，汃くてその所見について病 型を浮腫, 浸潤, 線維, 混合の4 型に分類し, 病変度を 軽度, 高度とわけ, この成績を臨床成績と対比した。 な扔一部症例については結合組織の状態を検討するた 好線猚型，混合型を示方症例を中心に20例について Elastica-Van Gieson 染色, Azan-Mallory 染色, PTAH (phosphotungustic acid hematoxylin) 染色など交行な い，その所見と臨床経過との関係も検索した．

\section{第 3 章 研究成續}

第 1 節 粘膜病型, 病変度々臨床経過上の関倸 研究に当つては先ず各症例につき上钼洞開空部粘膜を 表面上皮, その基底膜, 粘膜結合織乃至間質（分布する 線組織を含的る)の3者に便宜上分類し，表面上皮につ

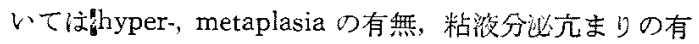
無を, 基底膜につマては肥厚の程度, 粘膜結合織につい ては緗胞浸潤の程度, 種颣, 浮腫の程度, 結合組織增殖 （fibrosis）の程度, 分布部位, 失腺組織については量 的に增えているか，内腔が cystic か，粘液がつまつてい るかどうか, 粘液腺細胞の hyper-, metaplasia, atrophy の有無, 血管については毛細血管, 動静脉の新生, 拡張 蛇行の有無, 血管壁の肥厚などについてその程度を榆 べ，その強さをH，，，士，一にて示した成績牥別表に 示す如くである。

以上の一般的な所見を総合して慢性上顎洞炎粘膜の病 型を浮婳型，浸潤型，線耀型，混合型上しその病変度を 相互比較に捛いて一応軽度，高度と分けた．この4 型に 関する定義或いは組織学的特徽（三として上皮下層）に ついては考按の項でふれるがその大要は次の如くであ る.

1. 浮尰型

粘膜の浮腫性腫脹が特銜的で細胞浸潤は極めて軽度で ある。

2. 浸潤型

著明な炎症細胞浸潤および增殖による粘膜肥厚があ る.

\section{3. 線維型}

結合組織線維が繳密に排列し，腺は萎縮し極めて少な ?.

\section{4. 混合型}

浮腿，緗胞浸㵎，線維化の中 2 者劣るいは 3 者がほぼ 


\begin{tabular}{|c|c|c|c|c|c|c|c|c|c|c|c|c|c|c|c|}
\hline \multirow{2}{*}{ 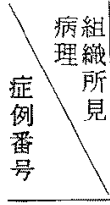 } & \multicolumn{2}{|l|}{ 上 } & \multirow{2}{*}{$\begin{array}{l}\text { 基 } \\
\text { 底 } \\
\text { 瞙 }\end{array}$} & \multicolumn{2}{|c|}{ 科 胞，浸 潤 } & \multirow{2}{*}{ 浮 } & \multirow{2}{*}{$\begin{array}{c}\text { 結合組緎 } \\
\text { 增 } \\
\text { 殖 }\end{array}$} & \multirow{2}{*}{$\frac{\text { 腺 }}{\text { 增。 }}$} & \multirow{2}{*}{$\begin{array}{l}\text { 組 } \\
\text { 粘 } \\
\text { 液 } \\
\text { 分 } \\
\text { 泌 }\end{array}$} & \multirow{2}{*}{ 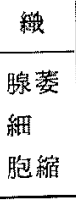 } & \multicolumn{2}{|l|}{ 血 } & \multirow{2}{*}{$\begin{array}{l}\text { 管 } \\
\text { 譬 } \\
\text { 肥 } \\
\text { 曆 }\end{array}$} & \multirow{2}{*}{$\begin{array}{l}\text { 粘 } \\
\text { 膜 } \\
\text { 病 } \\
\text { 型 }\end{array}$} & \multirow{2}{*}{$\begin{array}{l}\text { 病 } \\
\text { 変 } \\
\text { 度 }\end{array}$} \\
\hline & $\begin{array}{l}\text { 肥 } \\
\text { 唇 }\end{array}$ & $\begin{array}{l}\text { 化 分 } \\
\\
\text { 泌 } \\
\text { 芯 } \\
\text { 生 進 }\end{array}$ & & 度 & 類 & & & & & & 殖 & $\begin{array}{l}\text { 唗 } \\
\text { 浱 } \\
\text { 行 } \\
\text { 行 }\end{array}$ & & & \\
\hline 1 & + & + \pm & 正 & HI & $\mathrm{L}>\mathrm{P}$ & - & - & H & + & - & + & \pm & - & 浸 & 高度 \\
\hline 2 & & 明 & $\pi$ & H & $\mathrm{L} . \mathrm{P}$ & - & + & + & + & - & + & + & + & $"$ & 11 \\
\hline 3 & & -- & $" 1$ & \pm & L. E & H & + & \pm & \pm & - & \pm & + & - & 浮 & 高度 \\
\hline $\begin{array}{l}4 \\
5\end{array}$ & & $= \pm$ & $" \prime$ & & $\begin{array}{l}\mathrm{P}<\mathrm{L} \\
\mathrm{L}\end{array}$ & $\begin{array}{l}\text { H } \\
+\end{array}$ & $\begin{array}{l} \pm \\
\pm\end{array}$ & H & \pm & $\overline{-}$ & $\overrightarrow{+}$ & $\overline{+}$ & \pm & $\begin{array}{l}\text { 浸 } \\
\text { 浸 }\end{array}$ & 高度 \\
\hline 6 & + & $\pm \quad-$ & $" 1$ & + & $\mathrm{L}=\mathrm{P} . \mathrm{E}(t)$ & + & + & + & - & - & H & \# & H & $" \prime$ & \\
\hline 7 & - & \pm- & $" \prime$ & H & $\begin{array}{ll}L=P \\
L=P\end{array} \quad \begin{array}{l}E \\
E(+)\end{array}$ & \pm & \pm & - & H & + & H & + & + & $" \prime$ & $" \prime$ \\
\hline 8 & & - & $"$ & + & $\mathrm{L}=\mathrm{P}$ & \# & \pm & H & + & - & \pm & \pm & + & 浮 & 高庋 \\
\hline $\begin{array}{c}9 \\
10\end{array}$ & $\bar{t}$ & $\bar{t}$ & $" \prime$ & + & $\mathrm{L}=\mathrm{P} \quad \mathrm{E}(t)$ & + & \pm & \pm & $\begin{array}{l}t \\
+\end{array}$ & - & $\begin{array}{l}+ \\
\pm\end{array}$ & $\bar{t}$ & + & 混 & 整度 \\
\hline 1 & & - & & & L-I. L & $\perp$ & \pm & & $T$ & 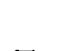 & & $T$ & & & \\
\hline $\begin{array}{l}11 \\
12\end{array}$ & - & $=-$ & $" \prime$ & \pm & $\mathrm{L}$ & \pm & t & + & $\bar{H}$ & $\overline{-}$ & $=$ & $\overline{-}$ & \pm & 被 & 俥至度 \\
\hline 13 & & 明 & & $\begin{array}{l}+ \\
+\end{array}$ & L. N & + & $\begin{array}{l} \pm \\
+\end{array}$ & $\vec{H}$ & + & - & + & - & + & 11 & 鋰度 \\
\hline 14 & - & -- & 正 & + & L. $E(+)$ & + & H & \pm & + & \pm & I1. & H & \# & 線 & 軽度 \\
\hline 15 & + & \pm & & H & $\overline{\mathrm{L}}=\overline{\mathrm{P}} \cdot \mathrm{R}(+)$ & - & + & \pm & + & \pm & + & - & + & 混 & 高度 \\
\hline 16 & - & - & & + & $\mathrm{L}=\mathrm{P}$ & \pm & + & \pm & \pm & - & + & + & H & 浸 & 軽度 \\
\hline 17 & - & - & IE & + & $\mathrm{L}=\mathrm{P} \cdot \mathrm{E}(t)$ & + & + & + & \pm & + & \pm & + & It & 混 & " \\
\hline 18 & + & \pm- & F & H & $\mathrm{L}>\mathrm{P}$ & \pm & $\#$ & \# & \pm & $\bar{t}$ & \pm & $\stackrel{+}{+}$ & I & 浮 & 高䓍 \\
\hline $\begin{array}{l}19 \\
20\end{array}$ & $\begin{array}{l} \pm \\
\pm\end{array}$ & \pm \pm & 步 & ti & $\begin{array}{l}\mathrm{L}=\mathrm{N}(+) \\
\mathrm{L}\end{array}$ & $\begin{array}{l}+1 \\
+\end{array}$ & $\begin{array}{l} \pm \\
\pm\end{array}$ & \pm & \pm & \pm & + & + & - & 浸 & $" \prime$ \\
\hline 21 & - & - & $" 1$ & \pm & $L>P$ & $t$ & + & + & + & + & + & \pm & + & 線 & \\
\hline 22 & \pm & - & $" \prime$ & + & $\mathrm{L}>\mathrm{P}$. & \# & \pm & \pm & \pm & \pm & \pm & H & \pm & 浮 & $" \prime$ \\
\hline 23 & & - & $" \prime$ & H & $\overline{\mathrm{L}}=\mathrm{P}$ & \pm & \pm & + & H & + & \pm & \pm & - & 浸 & $\prime \prime$ \\
\hline 24 & - & - \pm & $"$ & + & $\mathrm{L}<\mathrm{P} . \quad \mathrm{N}(+)$ & H & \pm & - & - & $\bar{z}$ & $\overline{+}$ & \pm & + & 浮 & "I \\
\hline 25 & & - \pm & $" \prime$ & \pm & $\mathrm{L}>\mathrm{P}$ & - & t & - & + & & & + & & & $" 1$ \\
\hline 26 & - & \pm & "I & \pm & $\mathrm{L}>\mathrm{P}$ & \pm & + & - & - & \pm & - & + & - & "I & 軽度 \\
\hline 27 & & \pm & $" \prime$ & \pm & & + & \pm & + & + & $\overline{-}$ & \pm & \pm & \pm & 浮 & $\prime \prime$ \\
\hline 28 & - & - & "I & H & $\mathrm{L} \gg \mathrm{P}$ & \pm & + & H & t & \pm & $\bar{z}$ & I & $\begin{array}{l}+ \\
+\end{array}$ & 受 & 高度 \\
\hline $\begin{array}{l}29 \\
30\end{array}$ & & $\overline{-}+$ & ゃ" & $\begin{array}{l} \pm \\
\pm\end{array}$ & $\stackrel{\mathrm{L}}{\mathrm{L}}=\mathrm{P}$ & H & $\stackrel{+}{ \pm}$ & + & $\stackrel{+}{ \pm}$ & $\begin{array}{l}+ \\
\pm\end{array}$ & $\bar{H}$ & \pm & H & 11 & $" 1$ \\
\hline 31 & 不 & & & + & $L=P \quad E(t)$ & - & + & + & \pm & \pm & \pm & \pm & H & 線 & $\prime \prime$ \\
\hline 32 & & $-H$ & & + & & H & + & H & it & \pm & + & + & H & 浮 & $" 1$ \\
\hline 33 & & $+t$ & 正 & \pm & & & + & - & - & \pm & + & + & + & 線 & 整度 \\
\hline $\begin{array}{l}34 \\
35\end{array}$ & & $-\quad \begin{array}{c}\text { 明 } \\
- \pm\end{array}$ & & $\begin{array}{l}+ \\
+\end{array}$ & $\underset{\mathrm{L}}{\mathrm{L}}=\mathrm{P} \cdot \mathrm{N}(+)$ & $\overline{-}$ & H & $\begin{array}{l}H \\
H\end{array}$ & $\stackrel{ \pm}{t}$ & - & $\begin{array}{l}+ \\
+\end{array}$ & $\begin{array}{l}+ \\
\pm\end{array}$ & H & 漫 & $\begin{array}{l}\text { 高安 } \\
\prime \prime\end{array}$ \\
\hline & - & - & 正 & \pm & & _ & + & + & H & - & \# & _- & t & $\prime \prime$ & 㱐度 \\
\hline $\begin{array}{l}36 \\
37\end{array}$ & - & - & 11 & + & $\mathrm{L}=\mathrm{P} . \mathrm{E}(t)$ & + & + & \pm & $\begin{array}{l}\pi \\
\pm\end{array}$ & - & H & + & H & 混 & 11 \\
\hline 38 & + & \pm & & \pm & & 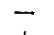 & + & \pm & + & + & \pm & - & \pm & 線 & $\prime \prime$ \\
\hline 39 & + & - & 正 & $t$ & L. $N(+)$ & \pm & t & \pm & - & - & \pm & + & \pm & $" \prime$ & 高度 \\
\hline 40 & + & + & $" 1$ & \pm & L. N. $E(t)$ & + & + & H & + & & + & & & & \\
\hline 41 & - & - & " & \pm & L. $E(t)$ & + & + & \pm & + & - & - & + & $H$ & 線 & " \\
\hline 42 & 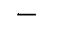 & 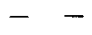 & " & + & $L>P . M(+)$ & H & + & \pm & + & - & - & \pm & - & 浖 & 高度 \\
\hline $\begin{array}{l}43 \\
44\end{array}$ & $\begin{array}{l} \pm \\
+\end{array}$ & $\overline{-} \overline{+}$ & "1 & + & $\begin{array}{l}\mathrm{L}=\mathrm{P} \\
\mathrm{L}>\mathrm{P} . \quad \mathrm{E}(t)\end{array}$ & $\stackrel{+}{+}$ & \pm & $\overline{-}$ & $\overline{-}$ & \pm & \pm & \pm & $\begin{array}{l}+ \\
\pm\end{array}$ & 浸 & 等度 \\
\hline & & & & & & & & & & & & & & & \\
\hline 45 & - & $-\quad-$ & 正 & \pm & $\mathrm{L}=\mathrm{P} . \mathrm{E}(+)$ & + & + & + & \pm & - & $H$ & $H$ & + & 粶 & 軽度 \\
\hline 46 & \pm & - \pm & & H & L. $E(+)$ & - & \pm & + & \pm & - & \pm & - & - & 浸 & 高度 \\
\hline $4 !$ & 不 & 明 & & \pm & & \pm & H & - & \pm & - & \pm & + & + & 線 & $" \prime$ \\
\hline 48 & - & + & & \pm & $\begin{array}{l}\mathrm{L}=\mathrm{P} \\
\mathrm{L}=\mathrm{P}\end{array}$ & + & \pm & + & H & \pm & $\frac{t}{+}$ & + & $\bar{t}$ & 学 & 整度 \\
\hline $\begin{array}{l}49 \\
50\end{array}$ & - & $-\quad-$ & 正 & H & $\begin{array}{l}\mathrm{L}=\mathrm{r} \\
\mathrm{L}=\mathrm{P}\end{array}$ & \pm & - & $t$ & + & \pm & \pm & \pm & + & 漫 & 高度 \\
\hline
\end{tabular}




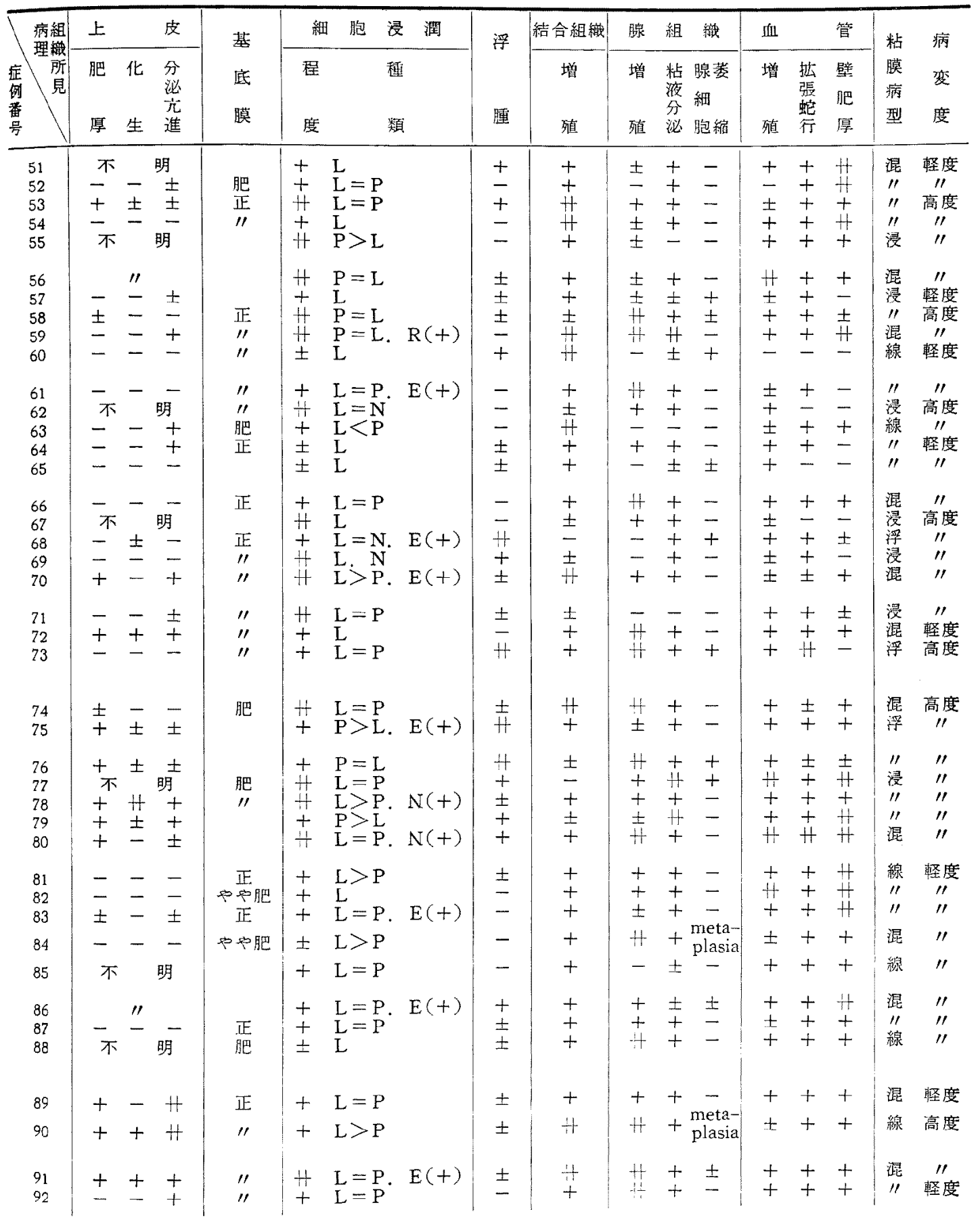

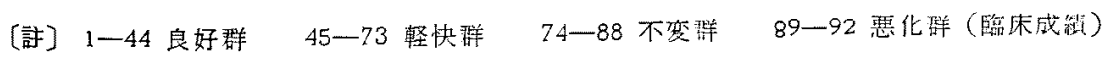


同程度に混在している。

その結果71人92例についての粘膜病型，病変度上前編 に記载した臨床経過における良好，軽快，不変，悪化各 群上の関保は第に表に示す如くである。

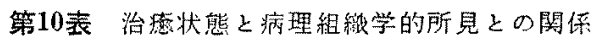

\begin{tabular}{|c|c|c|c|c|c|}
\hline 疼 & 臨床経過 & $\begin{array}{l}\text { 良奸磷 } \\
(44 \text { 例 })\end{array}$ & $\begin{array}{l}\text { 怪快翡 } \\
(29 \text { 例) }\end{array}$ & $\begin{array}{l}\text { 不変群 } \\
\text { (15例) }\end{array}$ & $\begin{array}{l}\text { 覀化群: } \\
\text { ( } 4 \text { 例) }\end{array}$ \\
\hline \multirow{4}{*}{ 軽 } & 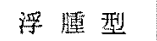 & 3 & 0 & 0 & 0 \\
\hline & 漫 潤 型 & 2 & 1 & 0 & 0 \\
\hline & 楾 触 型 & 3 & 5 & 5 & 0 \\
\hline & 混 合 型 & 3 & 4 & 2 & 2 \\
\hline 度 & $\overline{\bar{z}}$ & 11 & 10 & 7 & 2 \\
\hline \multirow{3}{*}{ 高 } & 浖雸 型 & 12 & 3 & 2 & 0 \\
\hline & 浸 潤 型 & 10 & 8 & 2 & 0 \\
\hline & 線 維 型 & 9 & 3 & 0 & 1 \\
\hline \multirow{2}{*}{ 度 } & 䍡 合 堽 & 2 & 5 & 3 & 1 \\
\hline & 壾 & 33 & 19 & 7 & 2 \\
\hline
\end{tabular}

第 2 節 粘膜病型，病変度七結合組緎線維との関係 前節で開空手術の術後経過との対比において密孔部粘 膜の病型, 病変度をその病理組織学的所見加ら判断した が，病変部に出兒する線維結合織を更に分析する目的で 92症例中, 線維, 混合両型を中心に20例について研究方 法の項で述べた如く結合組織線維, 寸なわち弾性線稚, 格子状線維，翏原線維の分布状態を検索した。

第11表 粘膜病型，病変度と結合組織線維分布 との関倸

\begin{tabular}{|c|c|c|c|c|c|c|c|c|c|c|}
\hline \multirow{2}{*}{\multicolumn{2}{|c|}{$\begin{array}{l}\text { 楾維 } \\
\text { 增愐度 } \\
\text { 病 } \\
\text { 䆣 } \\
\text { 度 } \\
\text { 粘膜 } \\
\text { 病型 } \\
\end{array}$}} & \multicolumn{3}{|c|}{ 弹性楾維 } & \multicolumn{3}{|c|}{ 格子状線維 } & \multicolumn{3}{|c|}{ 膠原楾維 } \\
\hline & & $\begin{array}{l}\text { 非 } \\
\text { 増 } \\
\text { 殖 }\end{array}$ & $\begin{array}{l}\text { 軽 } \\
\text { 度 } \\
\text { "I }\end{array}$ & $\begin{array}{l}\text { 高 } \\
\text { 度 } \\
\text { " }\end{array}$ & $\begin{array}{l}\text { 非 } \\
\text { 增 } \\
\text { 殖 }\end{array}$ & $\begin{array}{l}\text { 軖 } \\
\text { 度 } \\
\text { " }\end{array}$ & $\begin{array}{l}\text { 离 } \\
\text { 度 } \\
\text { "I }\end{array}$ & $\begin{array}{l}\text { 非 } \\
\text { 境 } \\
\text { 殖 }\end{array}$ & $\begin{array}{l}\text { 軗 } \\
\text { 度 } \\
\text { "I }\end{array}$ & $\begin{array}{l}\text { 商 } \\
\text { 度 } \\
\text { "I }\end{array}$ \\
\hline 軽 & $\begin{array}{l}\text { 浮腫型 } \\
\text { 浸潤型 }\end{array}$ & & & & & & & & & \\
\hline \multirow{2}{*}{ 度 } & 線維型 & 3 & & & 1 & 1 & 1 & & 3 & \\
\hline & 混合型 & 4 & 2 & & 2 & 2 & 2 & & 5 & 1 \\
\hline \multirow{2}{*}{ 高 } & 浮尰型 & 3 & & & 1 & 2 & & 1 & 2 & \\
\hline & 浸潤型 & & 1 & & & 1 & & 1 & & \\
\hline \multirow{2}{*}{ 度 } & 線維型 & 3 & 1 & 1 & 2 & 3 & & & & 5 \\
\hline & 混合型 & & 2 & 1 & & 1 & 2 & & 2 & 1 \\
\hline
\end{tabular}

1. 弾性線維
第12表 粘膜病型, 病变度と弹性楾維分有との 関係

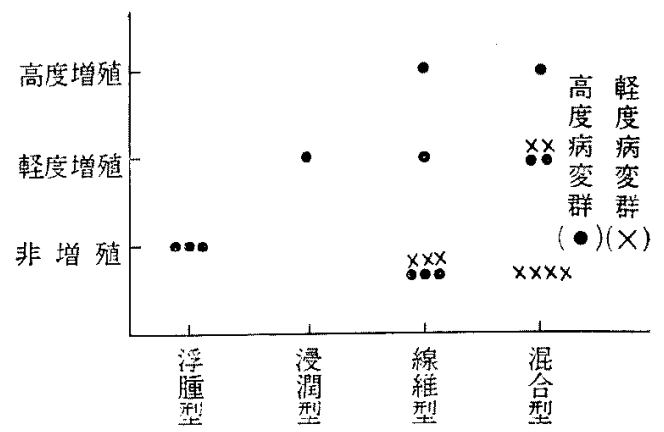

動静脉の血管壁，缼腫内壁および基底膜にみられた。 もつとも著明にみられるのは肥厚した動脉で内腔は圧迫 狭少となり，また叢状をなしているもの(Elastose)ある いは幾本かの細線維に分加れているもの(Elastolyse)な どがみられた，検索を行なつた20例の弾性線維の分布状 態孛非増殖，轻度，高度増殖で示すと第11表の如くであ りこれと粘膜病型との関倸をグラフで示すと第 12 表に 示すようになる。これより混合型高度病変群において9 例中 5 例が軽度〜高度增殖で㐫り，線維型の8 例中 2 例 よりも線維分布が強かつた。

\section{2. 格子状線維}

慢性上顎洞资経過においてこの線維の分布は基底膜，

第13表 粘膜病型，病窥度と格子状線維分布と の関倸

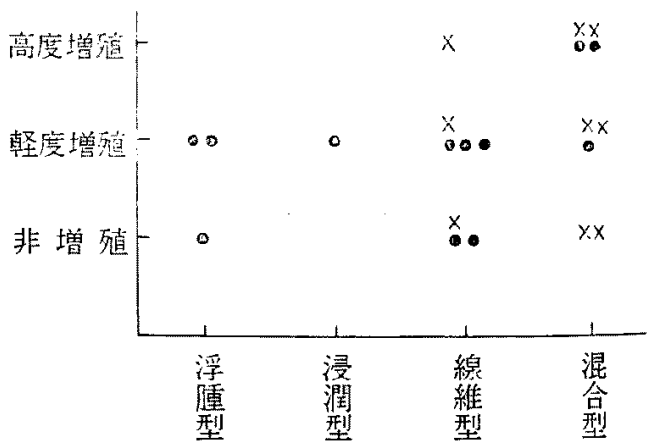

モ細血管，肥厚した血管壁，腺の周囲，翼腫内壁などに みられたこのうち固有尿の腺，露腫周囲には特に太い 線維が分布していた，粘膜病型，病変度とこの線維の分 布状態は第11表の如くである。これをグラフで示すと第 13表に示す如くである。混合型高度病変の場合この線維 
の分布が著明で，線維型においては特に多くなく膠原線 維の分布と並行子る傾向はみられなかつた。

\section{3. 琴原線維}

線維性結合組織の主成分である本線維の増殖は血管，

董睡などの周囲に限らず固有層に㕕く分布し，線維型に おいては上皮直下まで存在しあるいは密接，䅕密となつ て般痕様を示すものもみられる。血管壁の肥厚した部位 㞲琴原線維が著明で, 球状になつて腔内に入りこみ狭窄 を抗こしているもの，Eggston-Wolff ${ }^{202}$ の指摘する如く 完全に賿原線維でおきかわつている状態もみとかられる (fibrosclerosis).

粘膜病型, 病変度とこの線維の分布状態乞の関係は第 11表の如くでかり，グラフで示すと第14表に示すように なる、線維型高度の場合は大部分が膠原線維であり, 線 維芽細胞の減少と合わせ般痕化の㑯向思わせ，更に硝 子椂変性に陷つている所見もみられる。

第14表 粘膜病型，病变度と膠原線維分布と口 関係

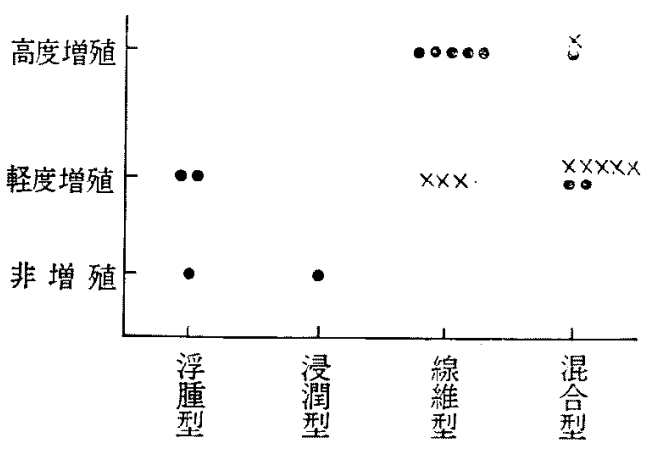

第 4 章 綜括並びに考按

まず初めに前章第1節に対する綜括ならびに考按を行 なうに，第10表より各粘膜病型に関して病変の軽度，高 度を比較して臨床程過をみると，総数的にはむしろ高度 病変型の方が経過息好の率が高い.しかしこのことは各 病型と病変度との比較が困難であるので，更に分析して 浮腫, 浸潤, 線維, 混合各型を別々に観察すると, 浮連 型および漫潤型においては軽度病変についても高度病変 についても何れむ臨床経過が良好な傾向がうかがわれ る.

線維型については高度病変の力が臨床経過の良好群に 属するものの率が高く，軽度病変についてはむしろ臨床 経過の不変群に属するものが多く，良好群に属するもの
が比較的少ない:

混合型については軽度，高度病変において臨床経過が 同じよ5な分布を示し粘膜病型, 病变度と臨床経過との 関連は不明確である。

そこで各粘膜病型について軽度病変と高度病変で臨床 経過の傾向について差遠があるかどうかを推計学的に調 ベた。

いま軽度病変, 高度病変仕臨床释過と無関係であると いう仮説を，幾つかの百分率の比較に用いられる $\chi^{2}$ 分 布2゙によつて唡定する。

$$
2 \times \mathrm{m} \text { 分割延 }(\mathrm{m}=4)
$$

\begin{tabular}{|c|c|c|c|c|c|}
\hline & $\mathrm{B}_{1}$ & $\mathrm{~B}_{2}$ & $\mathrm{~B}_{3}$ & $B_{4}$ & 棓十 \\
\hline$A_{1}$ & $\mathrm{n}_{11}$ & $\mathrm{r}_{12}$ & $\mathrm{n}_{13}$ & $\mathrm{n}_{1: 4}$ & $\mathrm{n}_{1}$ \\
\hline$A:$ & $\mathrm{n}_{\mathrm{n}_{1}}$ & $\mathrm{n}_{22}$ & $\mathrm{n}_{23}$ & $\mathrm{n}_{2,4}$ & $\mathrm{n}_{2}$ \\
\hline 詰十 & $\mathrm{n}_{*_{1}}$ & $n \cdot 2$ & $\mathrm{n} \cdot 3$ & $\mathrm{n} \cdot 1$ & $\mathrm{n}$ \\
\hline
\end{tabular}

$\mathrm{A}_{1}$ 船度病変 $\mathrm{A}_{2}$ 高度病恋

$\mathrm{B}_{1}$ 良好群 $\mathrm{B}_{2}$ 軽饮群 $\mathrm{B}_{3}$ 不变群 $\mathrm{B}_{4}$ 覀化群 $\mathrm{n}_{i j} \ldots$ 病変 $\mathrm{A}_{i}$ で臨床経過 $\mathrm{B}_{j}$ に属する症例数

$\mathrm{n} i .=\sum_{j=1}^{4} \mathrm{n}_{i j}, \mathrm{n} \cdot j=\sum_{i=1}^{2} \mathrm{n}_{i j}$,

分割表内の実測值 $n_{i j}$ に対する理婨值を $\frac{\mathrm{n}_{i} \times \mathrm{n}_{. j}}{\mathrm{n}}$ とし

$$
\tau \chi^{2} \text { の值は } \chi^{2}=\sum_{i=1}^{2} \sum_{j=1}^{4} \frac{\left(\mathrm{n}_{i j}-\frac{\mathrm{n}_{i} \times \mathrm{n} \cdot j}{\mathrm{n}}\right)^{2}}{\frac{\mathrm{n}_{i \cdot \times \mathrm{n} \cdot j}}{\mathrm{n}}}
$$

で与えられる。

自由度は $(2-1)(4-1)=3$ であり， $x^{2}$ 分布表上り有 意水準 0.050 值 $\chi_{3}^{2}(0.05)=7.81$ である.

浮腫型, 浸潤型, 混合型については $\chi_{2}$ の值は7.81上り 小さくなる故，仮説は有意であり，線維型については X $=9.5$ であり仮説は㲤却される。すなわち開空手術の 術後経過 ( 6 力月) において浮腫型, 浸潤型, 混合型に ついてはその病変度を軽度，高度に分けることは，あま り意味がなく，線維型については軽度と高度の病変の間 には意味をむつと解釉される。

すなわち浮腫型および浸潤型については軽度，高度病 変に拘わらす臨床的に治痱の傾向が強い，線維型につい ては高度病変の方が軽度病変より治瘾与る㑯向がみられ る. 混合型については整度，高度病变に拀ける臨床経過 に一定の僋向がみられない。

慢性副粤腔㷋の粘膜病型の分類に関しては古くは

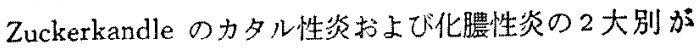


ある、ての後 Manasse ${ }^{28}$ は 1) 浮䀯型，2）肉芽型，3） 線維型に分類し，Nühsmann湆は1）力タル型，2）初 期化膿型，3）混合型に Hansel ${ }^{30}$ は 1) アレルギー型, 2) 二次的感染を伴なうアレルギー型，3）化膿型に分類 している。

しかしながら私は病理組織所見においてて粘膜結合織の 浮腫, 細胞浸潤, 線維增殖の模様が，ときにいずれを優 勢と決められないものがあることより Ballenger ${ }^{31)}$ の分 類に従つて浮挿型，浸潤型，線維型，混合型に分けた。 この各病型と開密手術の臨床成續（第10表）との関係は 以上に述べた通りである。しかしこれら各病型を基調と して今一度文献的考察老試みるに次のようである。

1 浮尰型

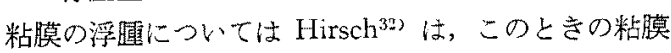
の厚さは10〜15倍にも増加し，慢性炎症では分必液はな く參出液が主で，しかも粘膜外に滲出するこ上は稀であ

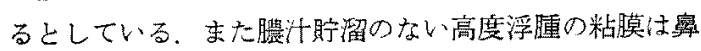
革の病理組織所見と一致しているため鼻茸は上顎洞より 発生するとした。

私の症例で浮腫型においては高度病変であつても良好 な経過をとつた例が多かつたのは，高度浮腫による自然 孔の開塞が空孔を作ることにより消裸して開き，細菌感 染が弱かつたことと共に好成績を示す原因となつたと考 えられる。たたしこの場合基礎に粘膜のアレルギーが存 在するか否かは重要である。奥田 ${ }^{33)}$ は慢性副鼻腔㭥の10 \%にアレルギー検查怔陽性であり，成因的にアレルギ一

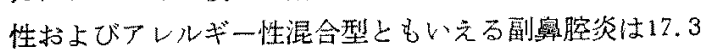
\%であり根治手術を行なつても鼻腔よりのアレルギー症 状はとれす，減感作療法，副腎皮質ホルモン，抗ヒス夕 ミン用の投与が必要であると述心ている。また後藤 (敏) ${ }^{3+3}$ は組織学的にこれがアレルギ一性副奥腔炎である

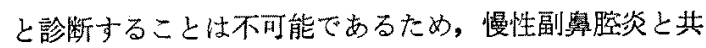
に上気道，身膑または全身に著明なテレルギ一性変化の

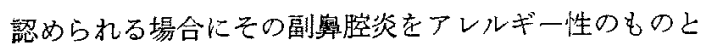
見做しておくことが臨床家にとつては確実な態度である うとしている.この点に関して今回の症例では組織学的 に從来よりアレルギー性病変として挙げられている基底 膜の肥厚，好酚球浸潤および血管壁のフィブリノイド変 性 $^{3035)}$ な゙の所見が一部にみられたが, 今回の研究の

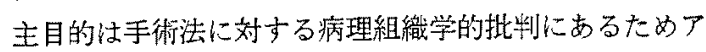
レルギー問題は一㐫諸家の見解圭記载するにとどめた W.

2 浸潤型
肉芽型 Manasse ${ }^{28)}$ ，感染型 Hansel ${ }^{30)}$ な゙とも呼ばれ 細菌感染にともなつてリンパ球，形翼細胞，好中球，好 酸球などの細胞浸潤が高度で一般に洞内に粘液，澧汁の 貯溜さ認めることが多い，ただ本型の中には HansenPruss ${ }^{362}$ のい5感染組織による細菌アレルギ一も含まれ ているかもしれない，菊地"4笹度炎症の際にはるる いは混合型を，あるいは浸潤型を生ずるが，泿合型は炎 症がさらに持続的となると, 貯溜液の影響で本型の所兒 走呈するに至り，部分的には細胞浸潤がつよく本型と区 別できなくなるという。

細胞漫潤は上皮直下に著明でリンパ沪胞を形成してい ることもあるが，腺周囲に強く浸潤していることもしば しばみられる。中野 ${ }^{37}$ は本型で，細胞浸潤により腺組織 の活動性が增強されることは少なく，むしる病変の強い 例に活動性の低下している傾向がめられたとしている。 開空手術時の洞内貯溜液の性状を示方第6表にお、て65 例の5ち紫，粘液性が20例 (31\%), 膿性が23例 (35\%) に含まれており，全体の66\%に貯溜液がみとめられた。

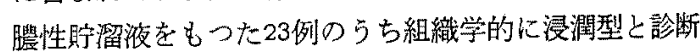
された症例は6例 $(23 \%)$ にすぎなかつたが，慢性炎症 の持続，二次的な感染による膿汁貯溜が考えられ病理組 織所晃と一致しないのは当然であるう．開密手術によつ て自然孔の閉鎖された上㖽洞に排泄路がつき，高度病変 であつても臨床的治撩が得られるのはVan Alyea ${ }^{33}$, Hempstead $^{(5)}$ らの主張するように drainage がつけられ ることに上り粘膜の修復加が保持されているためと考え られる。手術時に膿汁貯溜と脆弱で高度に浮腫性腫脹し 表面に小膿瘍を形成しているよらな粘膜に対しては膿瘍 の鉗除のみで開空手術を行なつた例もあるが，こ5した 粘膜では臨床的にもすでに回復能力はなくなつているも のとみられる、本型高度病変群で良好群と軽决, 不変群 が相半ばしているのはこうした症例と考えられた，估 藤 ${ }^{26)}$ は慢性副鼻腔炎において酸性ムコ多粕類の主成分で あるコンドロイチン硫酸全量 (Chondroitin sulphate A, B , C) が增量するが, その増加は化膿型, 浮腫型, 線維型の順に多いとし，正常粘膜中に含まれるコンドロ イチン硫酸の主体がB型であるのに対し，病的粘膜中に 含まれるコンドロイチン硫酸の主体が各粘膜病型ともC 型であるとし病態生化学的には最も治撚し難いことを推 測していることは示唆に富んでいる。

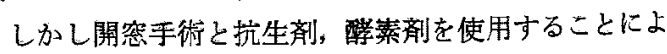
り高度病変であつても半数には良好な経過をみることは drainage と ventilation とは本型に対しても有就である 
と云わねばならない，

\section{3 線維型}

結合組織が表面上皮冝下まで配列し，しばしば肥厚し ているのが特徽的で血管壁も線維性の傾向を帯び肥厚著 明である．腺は莕縮し極めて少ない．本型に属する症例 は轻度, 高度病変群がほぼ同数であり, しかも高度病変 の方が軽度病変群より臨床経過がよいという結果に達し た.このことは一見矛盾した成績のようにも考えられる ので更に結合組織の詳細な観察を行なつたものにつきそ の部で改悋て考按を重变ることとする。

\section{4 混合型}

浮循, 浸潤, 線維型の 3 基本型中 2 者あるいは 3 者が ほぼ同程度に混在している型で慢性上须洞㷋粘膜の病型 としてはこの型に属するものはかなり多いここの型の中 には慢性炎症が軽微で組織学的に上記基本型のいずれか の病像を呈するまでに至つていない，後藤(敏) ${ }^{33)} の ら$ 「軽症型」も含まれると考えられる。持続する浮腫性変 化が漸次吸収され，その閒陵を代償性に補償するように 結合組織の堌加が加わつた場合，また中等度炎症では浸 潤型を生ずる上考えられるが鼻アレルギーに基ずく浮腫 が存在している場合なども考えられる，あるいは炎症像 が漸次消裉してくると成原線維の增加と血管壁の肥厚， 㹨窄も加わつて泿合型高度病変を呈することも考えられ る.

第10表に示すごとく軽度, 高度病変と臨床経過との間 には明白な相関々倸江認められず, 組織学的には浮腫,

漫潤，線維化何れの基本型も優勢上なり得す，治㽷状況 に関し，一定の方向ずけは存在せず良好，軽快，不変，

悪化の各群にいわば均等に分布せられているためるる種 の不定な状態を示しているといえるかもしれない，開空 手術が適応であるか，どらかも推測できなかつた。

次に前章第 2 節に対する綜括ならびに考按を行なら に, 本来結合組織の基本成分上しては形態学的に 1) 線 維成分，2）無定形のコロイド性間質成分 (基質)およ び3）細胞成分が挙げられている。この内線維成分は弾 性線維，格子状線維，圈原線維である。乙して近年これ ら線維の消長は慢性炎症の治熊機転をらかがう場合に一 つのポイントとみられるようになつた。弹性線維の主成 分である, elastin は非常に溶解しにくい線維性蛋白であ り,この線維の消長は病的状態と結びつくものと規定さ れているという(Jackson ${ }^{39)}$ ). 岡田 ${ }^{40)}$ は静脉壁の病変と して弹性線維増生による Elastose, 結合織増生による Fibrose のほかに平滑筋線䧽新生に上る muskúlärer
Umbau を挙げている，静脉壁間の平滑筋過剩発育と同 時に弹性線維も増生するが，弾性線維が著明になると筋 線維は潮次消失し終には静脉は閉鎖する。このとき弾性 線維は団塊となり采政となるが，こ机静脉の変化の最 後の状態々思われると述心゙ている。

弹性線維は動静脉血管壁，需蕾内壁などにみられるが 確かに静脉壁に特に著明な場合が多かつた。粘膜病型で は線維型に多く分布されるといら所見はみられず，混合 型においてわずかに多く分布する傾向がみられた，後藤 (修) $)^{229}$ は慢性上颚洞炎粘膜の間質線維の検索において線 維型では12例中例10に多数分布していると報告してい る。私の症例では 8 例中 2 例に多数分布がみとめられる のみであつた。弾性線維に関しては各粘膜病型で分布部 位および分布度化有意の差は認められなかつた。

格子状線維は1905年 Maresch が肝贜に Bielschowsky 氏神経線維鍍銀法を行ない緻密な線維網の存在を見出し たに初まるが，私は本法の岡氏変法を用いた，その結果 肥厚した血管の周困, 腺周囲, 基底膜のみでなく膠原線維 の存在部位にも微細な線維の分布をみ上めた，格子状線 維文膠原線維の分布と必ずしも並行せず，膠原線維の分 布の多い線維型では高度增殖は 8 例中 1 例であり, 混合 型では9例中 4 例より少ないことを示していた.このこ とは線維型では大部分の線維が翏原線維によつて構成さ れ，混合型では基本の粘膜型のいずれる優勢を示さない か，あるいは各病型の移行型と考えられるため格子状線 維が閦原線維の前段階であるとする説 (Rössle ${ }^{41)}$, Jack$\operatorname{son}^{399}$ ) よりすれば，この線維の分布は跈原化の停止像 といえるかもしれない：この線維の本態に関してRössle は炎症機転の際に格子状線維が gelatinize して周原線維 に移行するとして，松井诖は格子状線維が生理的及び病 的状態に扔いて容易に膠原線維に移行することから両者 は非常に接近した関保にあるとしている。これに対し後 藤(修)229雁原線維の増殖とともに格子状線維も増殖 し、殊に腺聜の搪大した周囲または溜胞の作成した部位 に著明に認められる加ら Rössle らの膠原線䧽への移行

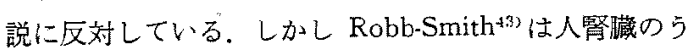
すい切片を稀い唒酸や菏性ソーダを含む種々な溶液で抽 出すると reticulinの構造あるいは染色性に何ら影響を 与えないが，膠原線維の染色性および肉芽組織の reticulin に著明な影響をもつことを見出しまた Gross ${ }^{44) ら ~}$ は, carrageenin granuloma を中性塩で抽出すると組織 の reticulinの鍍銀性をなくし，クエン酸緩衝液の抽出 で線維を完全に除去することを示し，結諭として発育し 
た結合組織の reticulinはすなわち collagen であり，そ れ故夷質性器官の基底膜の reticulin 上異なるとした。

私の検索において基底膜の格子状線維と上皮下層の格 子状線襍の增殖はほぼ並行する傾向がみられたが（12例 中10例)，後者の格子状線維洨線維型で特に增加してい るとは考えられず，混合型の方がむしろ分布が多いこと から, 格子状線維が賿原線維比移行することはありうる と思われた。

膠原線維の分布恃線維型に执いて最も著明であること は当然である，高度線維型の廖原線維は分布が密である ばかりでなく，波状の線維構造を呈し線維芽細胞などの 結合組織細胞がそしいが，軽度線倠型の場合には比較的 瀻細な線維よりなり結合組織細胞が多く分布している。 また線維分布軽度とした症例の中には結合組織細胞がそ しく，しか子染色性の弱、無構造な性状を呈する部位が みられた。これは線維構造にまで発育し得ない前段階で あるのか，支るい後藤(修) 維が硝子様変性，アミロイド変性などをおこしている場 合かと考えられるが判然としない．

Jakson ${ }^{39}$ によると国原線維の成分である collagen は 高浱度の proline, hydroxy-proline, glycine と低濃度の tyrosine の上うな芳香族アミノ酸との特殊なアミノ酸混 合物であるといい, collagen に強い処厧（特に酸性に するとか温度を上げるとか）をすると，コラーゲン特有 の線維の形に再構成されることのない gelatin になつて しまうという。このような研究からコラーゲン分子は特 徽的な,コラーゲン線維に直接組織化されらる最小の単 位と定義され，tropocollagen と呼ばれている (Gross, Highberger $\left.{ }^{45}\right)$.

これらのコラーグン分子より翏原線維形成をおこなう のは fibroblast であるといわれている．結合線維緗胞を はじめて記載した Schwann は膠原線維は細胞から直接 発育するとし，Virchow 注 fibroblast が細胞外で細線 維となる可溶性物質を分泌するこ上を指摘し今日ではこ の考えが一般的となつた (Jackson $\left.{ }^{39}\right)$.

Porter \& Vanamee ${ }^{46)}$ は fibroblast の組織培盖の研究 で最も初期の線維仙 fibroblastの表面でみられ，細胞外 の非線維性 (non-fibrillar) 基質の添加によつて発育する ことを示した。

また最近の電子顥微鏡的所見による上 fibroblast の細 胞質内に注原始楾㒕㐫るいは fibroglia 亡称すべき微細 な線維が形成され，それが細胞外に排出されて線維に成 熟することが見出されている(佐藤泉 $\left.{ }^{6}\right)$ ）細胞内で，あ
る type の crosslinking によつてコラーゲン分子の集合 により線維性蛩白が形成され，そ机が分必されて基質内 での線維形成の核上なることは，功な一般的な現象と 考えられ，それが基質内で多楉類その他をとり入れて楾 維に成長する上される(北条 ${ }^{62)}$ ).

このように考えてくると結合組樴細胞を伴なら絨細な 線維の分布よりは結合組織細胞のそしい太い，波状をな 寸線維の分布する粘膜病変の方が、炎症後の肉芽様組織 の滦痕化への過程を示寸と考えられる.従つて fibroblast による琴原線維形成，多くの毛細血管の退行，消失によ る搬痕化の過程よりすれば, 線維型高度の方が線維型軽

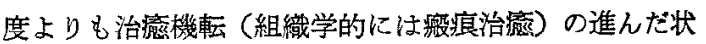
態であり、ここにも開空手術の有効性を実証する事夷が 存在することとなる.

\section{第 5 章 結語}

漫性上顎洞炎に対し開空手術を行なう際に対孔部の上 颚洞粘膜を採取し，その病理組織所見を検索し，その粘 膜病型を浮腫, 浸潤, 線維, 湜合型の 4 型に分け，その 病変度を柽度, 高度とした, 粘膜病型, 病変度と臨床経 過との関保より次のことが結論された。

1 浮腫型に関しては開空手術による成績は良好であ る.

2 浸潤型も一般的には抗生剂, 醇素剂の併用により 開空手衍でかなり良好な成績を举げることができる。

3 線維型に関しては結合組織の高度に分布する場合 の方が軽度の場合より臨床経過がよいという結果に達し た。

4 混合型については臨床経過との関係については一 定の相関々係をみとめることが困難であつた．

更に開空手術症例のちち線維型, 混合型を中心に20例 に結合組織の特殊染色を行ない, 弹性線維, 格子状線 維, 翏原線維の分布状態と粘膜病型との関保を検べ次の 結果を得な。

1 弹性線維は血管壁, 賴嗹内壁などにみられるが, 粘膜病型との関倸注明らかでなかつた。

2 格子状線維は結合組織增殖の多い線維型よりもを 乙ろ混合型の方に多く分布し，賿惊線維一の移行が考え られた。

3 膠原線維については線維型高度ではその増殖が強 くみられ，毛細血管の退行，消失，腺の萎縮，減少など によつて般痕化が進み臨床的に治㴽に向つていると予想 された。従つてここにも開空手術の存在意義が認められ る, 
1. 経過良好の対孔部所見

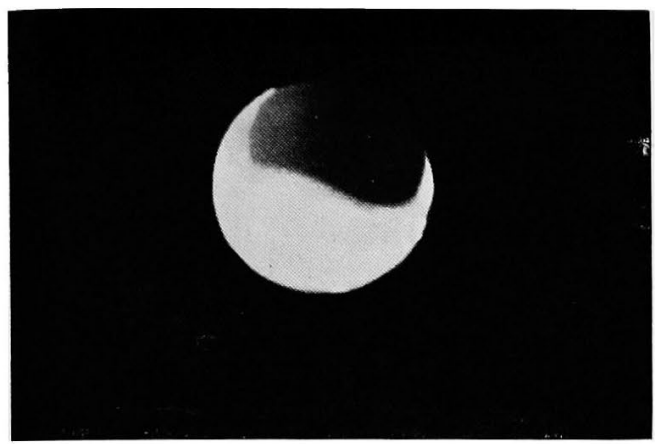

3. 経過不変の上顎洞粘膜

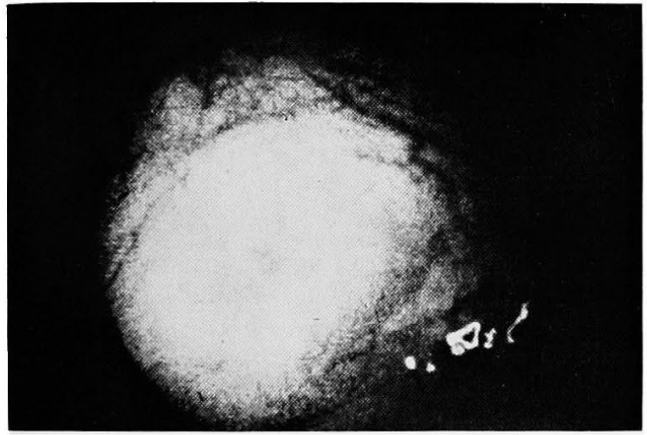

5. 浮腫型高度; 臨床経過不変 ( $\times 100$ 倍. H. E染任)

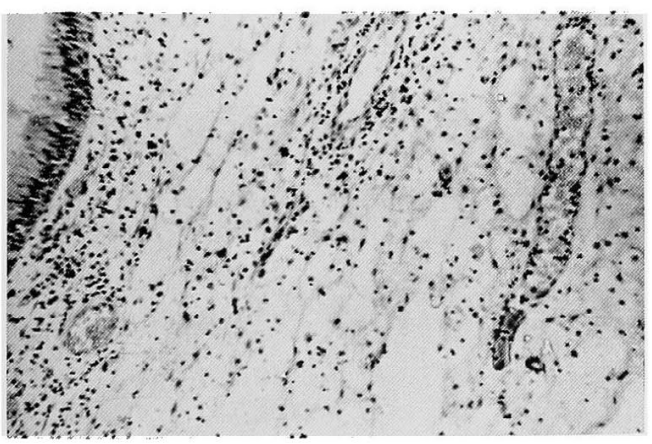

7. 浸潤型高度; 臨床経過不变 $(\times 100$ 倍. H. E染们)

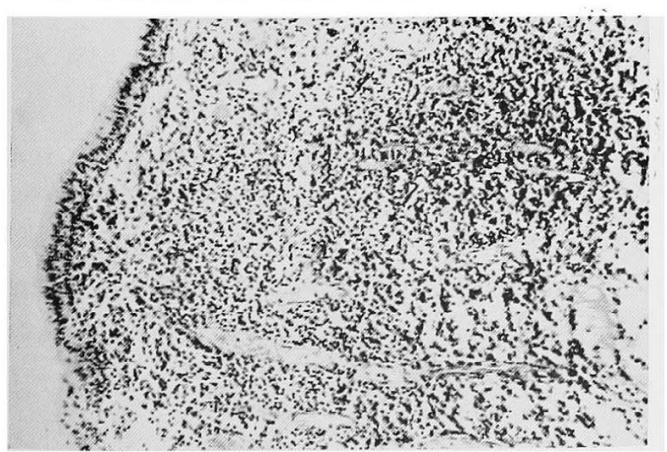

2. 経過不良の対孔部所見

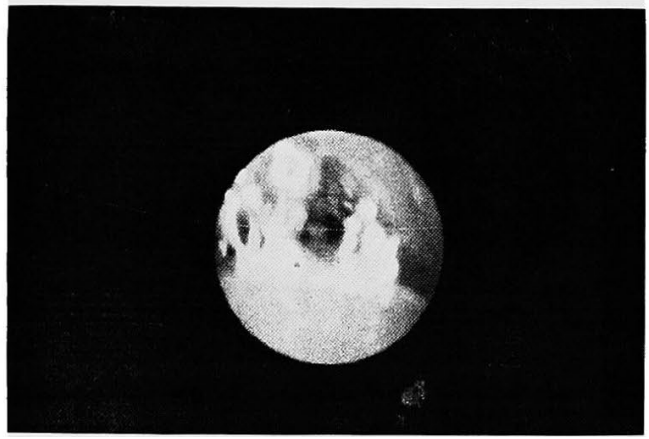

4 浮腫型軽度; 臨床経過良好（×100倍. H. E染色）

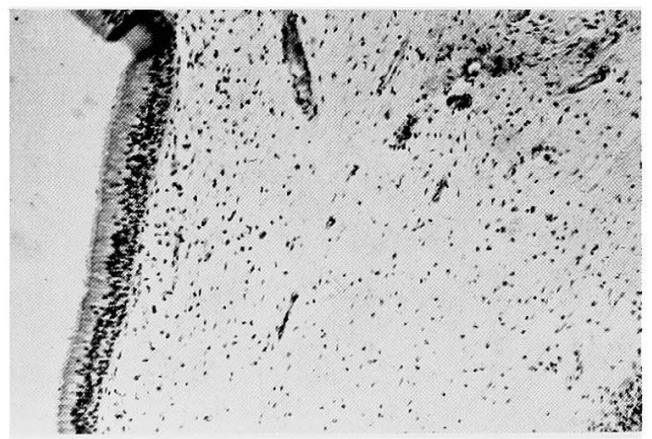

6. 浸潤型高度; 臨床経過良好（×100偣. H. E染色）

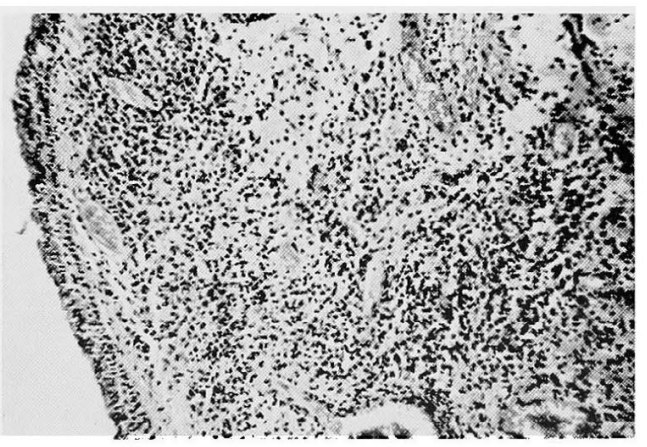

8. 線緋型軽度; 臨床経過良好 (×100偣. H. E 染他)

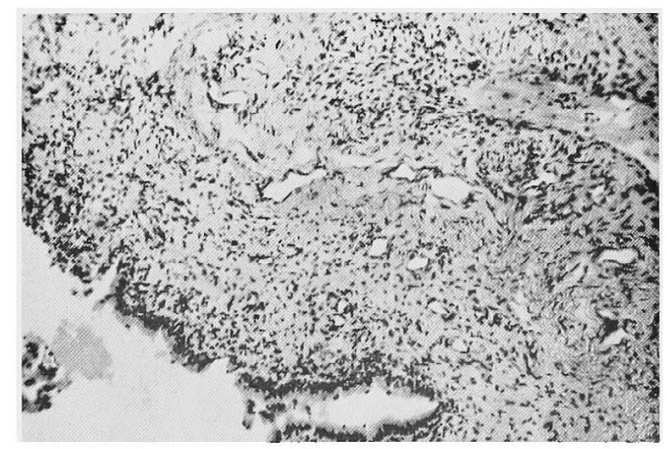


9. 線維型高度; 嵒休経過良行（×100倍. H. E染巴）

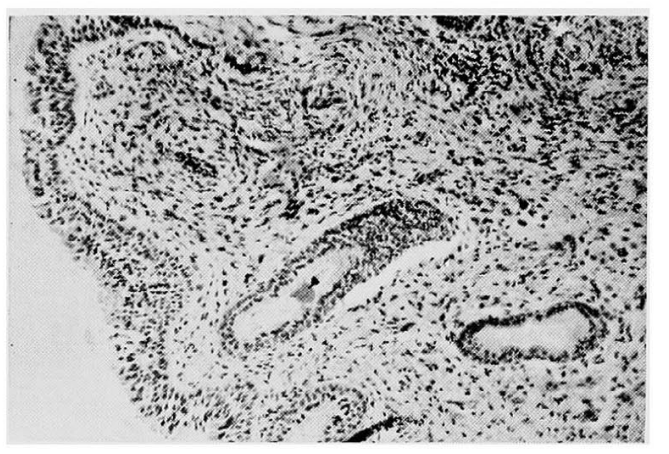

11. 混合型高度; 嵒床程渦不变 ( × 100 儅. H. E染们)

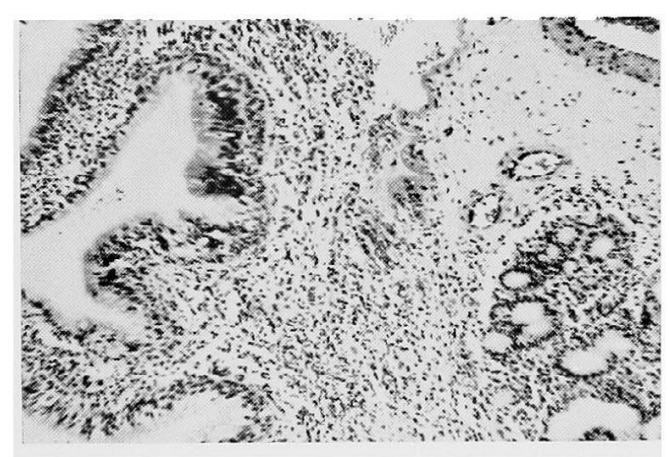

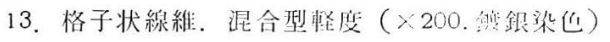

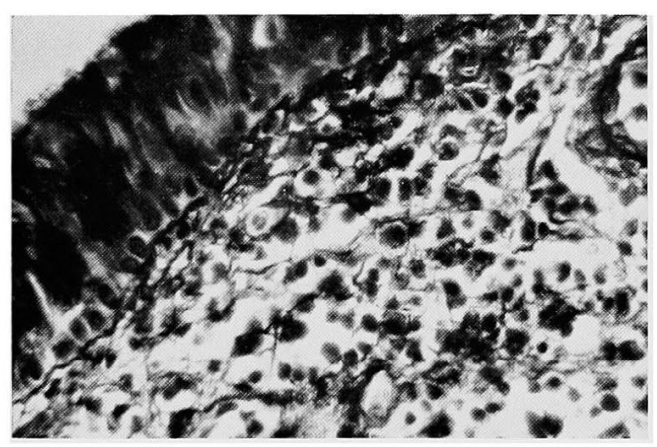

10. 混合型怪度; 郜床経過不变 ( $\times 100$ 倍. H. E染色)

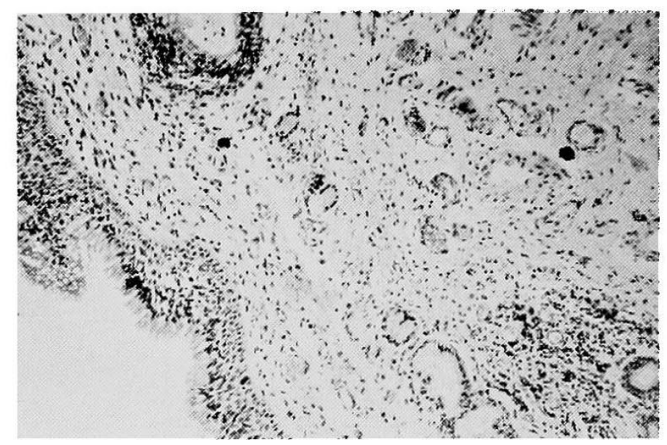

12. 弹性線維。Elastclyse (们管些) ( $\times 200$. elastica-Vin Giescn 染化)

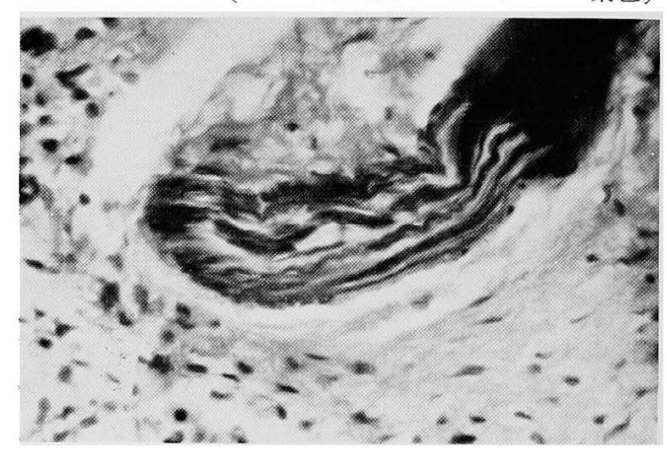

14. 胉線維。線維型高度（×200. A zan-Mallcry染色）

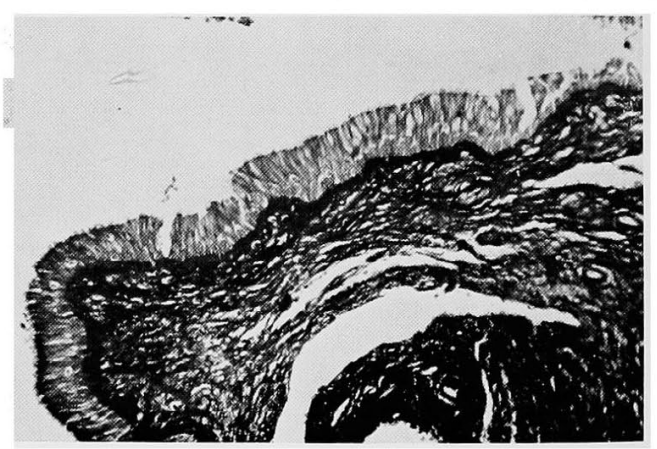




\section{III 全編に対する総括ならびに考按}

以上に枕いて開密手術後の臨床成績ならびにそれと手 術時の上顎洞内の諸状態，粘膜自身また性空孔自身の治

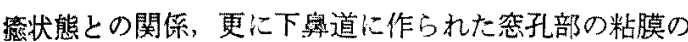
病理組織学的所見古るい证ての粘膜における結合組織上 の関係などの成績を記述するととむに，そのことに関し

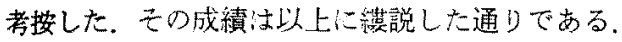

しかしながら以上を通じ更に少しく考按を追加する

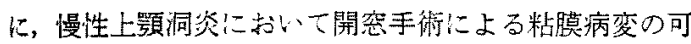

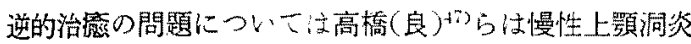
のレ線機能検查法において中等度の粘膜病変を示すビマ ン限局型，相当顕著な洞粘膜病変索示す限局型において も保存手術の有効であるこ上さ述心ている。ただこれに 対し後藤(敏) ${ }^{34)}$ 蛅膜病变の軽い「軽症型」あるいは 「末定型」に属するような症例では加えつて対孔が開け られることによつて感染，㷋症なおこして悪化する可能 性があるとしている、しかし一方，赤池 ${ }^{(8)}$ は根治手術後 の術創に洞の病的粘膜を移植しての後の急性感嘪時など も排泄障害がなく慢性化することもなく優れた方法であ ると述べている，また Bauer怆急性㧍よび慢性资症 の際の舆腔と副鼻腔粘膜上の組織学的な比較研究におい て, 鼻腔の急性症状の間に洞粘膜には殆んど変化はな く, 逆に洞粘膜の感染のときには察腔粘膜にも同様の炎 逢があると述心ている。

これに対し私の症例では開空手術によつて治澺在得ら れる症例にあつては感冒による侵䧶では殆んど影響はな い上らに考えれた。

次に粘膜の各種病型について考えるに, Hansel ${ }^{303}$ は純 隺なアレルギー反応に基うく変化として浮腫型と同様な 粘膜所見および高度な好酸球浸潤を特徽として挙げてい

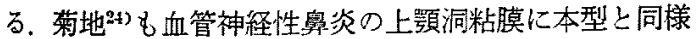
な所見を認めている。.Uffenorde ${ }^{18)}$, Hirsch $^{32)}$ らは血管 壁の変化，透過性の增加などによる浮腫を獎液性㷋と呼 び特殊な炎症と認めている。しかし Altschuler \& An-

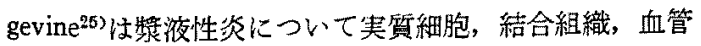
内被細胞などの hematoparenchymal system 相互間の 損賃による実貿細胞と毛細血管との間の離断によつて結 合組織内に蛋白質に富む殄出液が集積寸るためとしてい る。結合組織がこの hematoparenchymal system に㧤 いて必須の役割をしており，弥に結合組織内の hyaluronidase の作用による基澌の解重合(depolymerization)を 重視している，Salinger ${ }^{50)}$ はポリープ様組織において酸
性么二多糖類基質を見出し，結合組織間基質は血管内被 細胞および初期の fibroblast の活動の結果であることよ り，ポリープは浮腫性粘茣でありむしろ慢性刺戙に対す る結合組織の反応であるとしている。こうした粘膜病変 に対しては粘膜剝雕を行ならよりも開空手術を行ない, あるいはこれに抗ヒスタミン剤，副繁皮翼ホルモンなど の control を加えるこよの方がより合理的と考えられ $乃^{33 \times 512}$

浸潤型において開空手術の臨床経過において良好群 が半数を占めていたことは, 自然排泄口の閉塞による分 泌液の貯溜，線毛機能の障害に drainage がえられるた

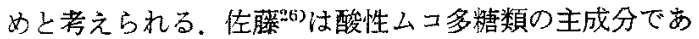
るコンドロイチン硫酸の定量で，慢性副奥腔炎における 增加方化膿型, 浮腫型, 湶維型の順に多く病態生化学的 には最も治稜し難いとしていることは興味がある，結局 本型の大部分任粘膜の修復能力は保持されているとみて よく，開空手術の適応と考えられ，薬物療法を適切に行 なうことにより一層治療成績を上げることす可能と思わ 丸る

線維型については active な炎症の消褪に引きつづい て，反応としての結合組織の増殖が含まれることは当然 考えられるとこるである。すなわち次症の消袏に伴なつ て㵶細な線維は太、琴原線維になり，結合組織細胞の少 なくなつてきている状態では痸痕化の病像として羿めら れる、したがつて本型については菊地24)の考察する如く 長期間持続する軽度の炎症による結合組織の増殖であつ ても，他型より烦症の消裸に伴なら結合組織の增殖によ る場合であつても開害手術は有効であると考えられる。

混合型については扛項後編に述べた通りである。

なお線維型については高度病変の方が軽度病変より開 空手術後の治湓傾向がよいという結果がみられたため， 線維型，混合型を中心に20例について結合組䋨の特殊染 色を行なつて弾性線維, 格子状線維, 琴原線維の分布に ついて検索した，その結果弾性線維の分布は各粘膜病型 について有意の差はみられなかつた。

格子状線維の分布汢肥厚した血管壁，腺周因，基底膜 などに著明であるが，また膠原線維の増殖部位にも微細 な線維構造 (密網) をみとめる。しかし膠原線維の分布 と必ずしb並行せず線維型に招ける高度分布は8 例中 1 例であり，混合型における9例中 3 例に比して少なかつ た.このこと性線維型では結合組織の大部分が既原線維 により構成され，混合型では結合組織の分布が少ないと 同時に，格子状線維が夙原線維の前段階であると才る説 
(Rössle)ょりすれば，結合組織線維の発育が低いとも 考えられた：この点で格子状線維の多い混合型は後藤 (敏 $)^{34}$ のい5「軽症型」を含めて，一定の病型を示さず 不定な病像を表わし開空手術の術後経過も予測できない が，線維型では結合組織は生長した翏原線維上り構成さ れ炎症状態の消裉過程の状態であり，開空手術が有効で あると考えられる. Jackson は Coons \& Kaplan 法に よつて螢光を発するようになる anti-glomerulus 血清が 基底膜 reticulin を染めるが閦原線維を染めず，このこ とは collagenの中に存在しない抗原が reticulin の構成 タ分であることを示しているといら、私の検索において は基底膜の格子状線維上固有層結合組織の格子状線維の 增殖はほぼ並行し12例中10例において一致していた。

囯原線維の形成に関しては繊絊な fibril より fiber に なる過程の物理的条件の規定要素として Gross 注基質の 酸性多糖体在重要視し，「もし酸性多糖体がなれけば fiber はもつれた禾のようになるだろう」と述べている といら (箱守 ${ }^{53)}$ ).

$$
\text { IV 結 語 }
$$

（1）慢性上腼洞炎者71人92例に対して開空手術を行な つたところ, 半年後において経過の良好群 $48 \%$, 軽快群 $32 \%$ ，不変群 $16 \%$ ，悪化群 $4 \%$ を示し，この成積は Caldwell-Luc 氏手術に匹敵するものであつた.

（2）手術時に採取した上颚洞空孔部粘膜の病理組織学 的検索を行なつて粘膜病型を浮腫型, 浸潤型, 線維型, 混合型に分け, その病変度を軽度, 高度とし, 術後 6 力 月の臨床経過と粘膜病型, 病变度との関倸を観察すると 次のようであった。

1 浮隀型, 浸潤型については怪度, 高度病変に拘わ らず臨床経過住良好であつて開空手術の適応と考えられ る.

2 線維型については高度病変の方が軽度病変より治 瘾傾向が高く，本型もまた開空手術の適応と考えられ 万.

3 混合型については軽度, 高度病変における臨床経 過に一定の傾向がみら机ず開空手術の適否は推察できな $\checkmark$.

（3）線維型については線維成分を更に染色的に分ち次 の結論をえた。

1 弹性線維の分布は血管壁, 覇腫内壁にみられる が, 粘膜病型との間には何らの関倸もみられなかつた。

2 格子状線維は結合組織増殖の多い線維型よりも,
むしろ混合型の方に多く分布し，圈原線維への移行が考 えられた.

3 線維型では成熟した网原線維の増殖, 毛細血管の 退行, 消失, 腺の萎縮減少などが多く, 組織の修復機転 が進んでいると解釈され臨床成績のよいことが裹書きさ れた。

\section{参考文献}

1) Ziegelmann, E.F.: A Ccnstructive Analysis of Maxillary Sinus Surgery. Surg. Gynec. \& Obst. 61 ; 388, 1953. 2) Mikulicz, T.: Zur cperativen Behandlung des Empyems der Highmorshöhle. Arch. f. kl. Chir. $34 ; 473,1886.3$ 3) Van Alyea, O.E.: Sinusitis ; What It is and What It is not. Postgr. Med. 34;

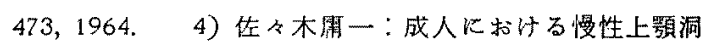
炎纪対する開空手術之根治手術法々の比較（臨床的研

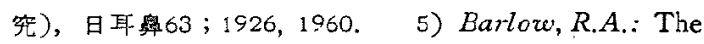
Value of Conservative Intranesal Drainege for Chronic Empyema of the Antrum. Minnesata Med. 4; 445, 1921. 6) Hempstead, B.E.: Intranisal Surgical Treatment of Clronic Maxillary Sinusitis. Arch. of Otolaryng. 6;426, 1927. 7) Goodyear, H.M. : Intranasal Surgery of the Maxillary Sinus. Arch. of Otolaryng. $50 ； 795,1949.8$ 8) 名越好古：副整炎 手術後の治湶㙨転とその障害について, 耳喉科, 36;977 1964. 9) Zuckerkandle, : Zitiert von Nühsmann. Antritis Maxillaris Chrcnica (Aetiologie und Pathogenese). Denker u. Kahlers Handbuch Bd 2; 705, 1926.

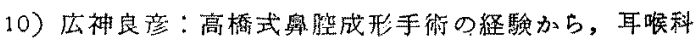

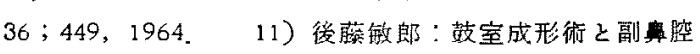
手術々に括ける共通的問題一粘膜残置, 空腔開放, 空 腔充塞の問題一，日耳舅，68；857，1965。12）高棉

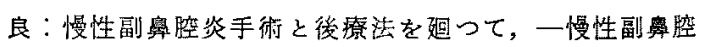

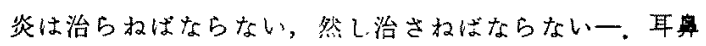
展, 6;144,1963。13）高須賀信尖: Antrum Window Operation 再手術例の検討, 曰耳臿, 65；1088, 1962.

14) Zuckerkandle, : zitiert ven Stevnson, W.:Chronic Maxillary Sinusitis, Arch. Otolaryng. 13; 506, 1931. 15) Stevenson, W.: Chronic Moxillary Sinusitis. Arch. Otolaryng. $13 ; 506,1931$. 16) Zuckerkandle, : Normale u. path. Anat. Nasenhöhle u. ihrer pneumat. Anhänge, Bd 1 \& 2., $1893 . \quad$ 17) Hajek, M.: Pathologie u. Therapie d. Entzundlichen Erkrankungen der Nebenhöhlen der Nase, 1915.18 ) Uffenorde, $W$. : 
Ueber katarrhalische Nebenhöhlen-entzündung und deren Diagnose. Monatschr. für O.L.R. $59 ; 308$, 1925. 19) Schumacher, S.: Histologie der Luftwege und der Mundhohle. Denker u. Kahlers Handbuch Bd 1; 308, 1925. 20) Eggston, A.A.\& Wolff, D.: Histopathology of the ear, nose and throat. WilliamsWilkins Co. 1947. 21) 美 日永：慢性舆炎㧍上び副 舅船炎以関する研究。京城医紀要：4；408，1934. 22) 後藤修二：僈性上顎䆩炎粘膜の病理組織学的所見並

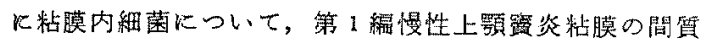
センイについて，日耳鼻41；1619，1935，23）西端驩 一：慢性副番腔炎の研究. 医学書院。1946. 24) 菊地 正吾: 慢性副鬼腔炎の病理組織学的矿㚾, 日耳率, 58; 206, 1955. 25) Altschuler, C. H. \& Angevine, D. $M$. : Histochemical studies on the pathogenesis of fibrinoid. Am. J. Path. 25 ; 1062, 1949. 26) 位藤良

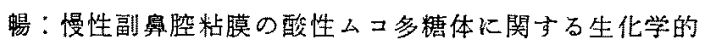
研究。日耳鼻。 $69 ; 1038,1966,27)$ 杉田腪道: 例解 医学統計入門，40，1964，中央医畵. 28) Manasse, $R$. : Die Pathologische Anatomie des Nebenhöhleneiterungen. Z. sch. Hals-usw. Heilk. Bd. 4. 473, 1923. 29) Nühsmann, T. : Denker-kahlers Handbuch. Bd. 2. 1926. 30) Hansel, F.K.: Histopathology of Acute and Chronic Infection of the Nose and Paranasal Sinuses. Allergy of the Nose and Parsnasal Sinuses. 131, 1936. 31) Ballenger, W.T. 他: Diseases of the Nose, Throat and Ear. 159, 1949. Philadelphia.

32) Hirsch, O.: Ueber katarrhalische Nebenhöhlenentzundung und deren Diagnose. Monat schr. f. Ohrenheilk. u. Laryng. Rhin. 58 ; 1043, $1924 . \quad 33)$ 奥田 稳他：鼻粘膜炎症と体質をめくる問題，一慢性副鼻腔炎 とアトピー型フレルギーについて一。耳喉科，37；731， 1965. 34) 後紫敏郎：慢性副鼻堙奖治療の根本的熊 度. 耳臨, $51 ； 47,1958$. 35) Beitzke, H.: Atmungsorgane, Nase u. Nebenhöhlen. Aschoffs Path. Anat. 7 ; 262, 1928. 36) Hansen-Pruss, O.C.: Bacterial Allergy and the Importance of Otolaryngological Procedures. Laryngos. 59 ; 540, 1945. 37) 中野浩: 含気腔学的にみた上顎洞粘膜の分泌腺之慢性上顎洞炎に よるその形熊の変化に関する研究。日耳为，69；819，

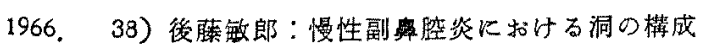
坊よび粘膜反応の原則について，日耳鼻，67；859， 1964. 39) Jackson, D.S.: Some Biochemical Aspects of Fibrogenesis and Wound Healing. New Engl. J. of Med. 259；814，1958.40）岡田博龙：慢性上顎洞炎 粘膜の病理組維学的研究。日耳奥, 64；1240，1961。 41) Rössle, R.: Ueber die Metaplasie von Gitterfasern bei wahrer Hypertrophie der Leber. Verhandl. d. deutsch. Path. Gesell. 12，1908. 42) 松井芳雄：生理

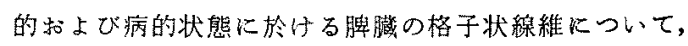
北越医誌。29；14，1914，43）Robb-Smith，A.H.: What is Reticulin? In Council for International Organization of Medical Sciences. Symposium on Connective Tissue, London, $172,1957$. 44) Gross, J.: Studies on Formation of Collagen; Influence of Growth Rate on Neutral Salts Extracts of Guenea Pig Dermis. J. Exper. Med. 107 ; 265, 1958 4 45) Gross, J., Highberger, J.H.: Collagen Structure considered as State of Aggregation of Kinetic Unit: tropocollagen. Proc. Nat. Acad. Sc. 40;678, $1954 . \quad 46)$ Porter, $K . R . \&$ Venamee, Observations on Formation of Connective Tissue Fibers. Proc. Soc. Exper. Biol. \& Med. $71 ； 513 ， 1949.47)$ 高橋 良他：レ線的機能

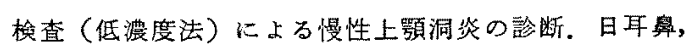
$98 ； 10$ 号専門講连 5，1965。48）赤池清美：赤池式 Sinoplastik 後の泪創の経過飞就て。日耳鼻，67；1621, 1964. 49) Bauer, E.: Vergleichende Histologische Untersuchungen der Nasen- und Kieferhöhlenschleimhaut. Arch. O.N. K. Heilk. 173 ; 160, $1958 . \quad 50)$ Salinger, S.: Progress in Otolaryngology, The Paranasal Sinuses. Arch. of Otolaryng. $73 ; 196,1961$.

51) Bryan, T.K.: Modern Treatment of Sinusitis. Arch. Otolaryng. $65 ; 567,1957.52)$ 北条摩一: 㓣 隽治撚之膠原。医学のあゆみ，48；65，1964. 53）箱 等仙一郎: 秸合組織成分の化学とその代謝。最新医学. $16 ; 1782,1961$.

稿を終る臨み，終始御愁篤なる御指酎，御校閲 を睗放りした恩師柏戸貞一教授扣よひ病理組䅧学 的に御指導，御校閲をいたたきました吉村羡之教授 に深甚の謝意を搽するとともに，御助言，御協力を 戴きました沢木修二助教授，大灀格博士並ひ长教室 員各位に感謝致します。

本諭文の要旨は第 412 回関東地方会例会，第4 回

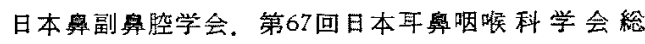
会. 第6 回日本奥副鼻腔学会括よび国際奥科学会 
Extraordinary Meeting of the International Rhinologic Society (S.40.10.20. 京都) と未いて未ぬ 発表した。 